\title{
Brookian Sequence Well Log Correlation Sections and Occurrence of Gas Hydrates, North-Central North Slope, Alaska
}

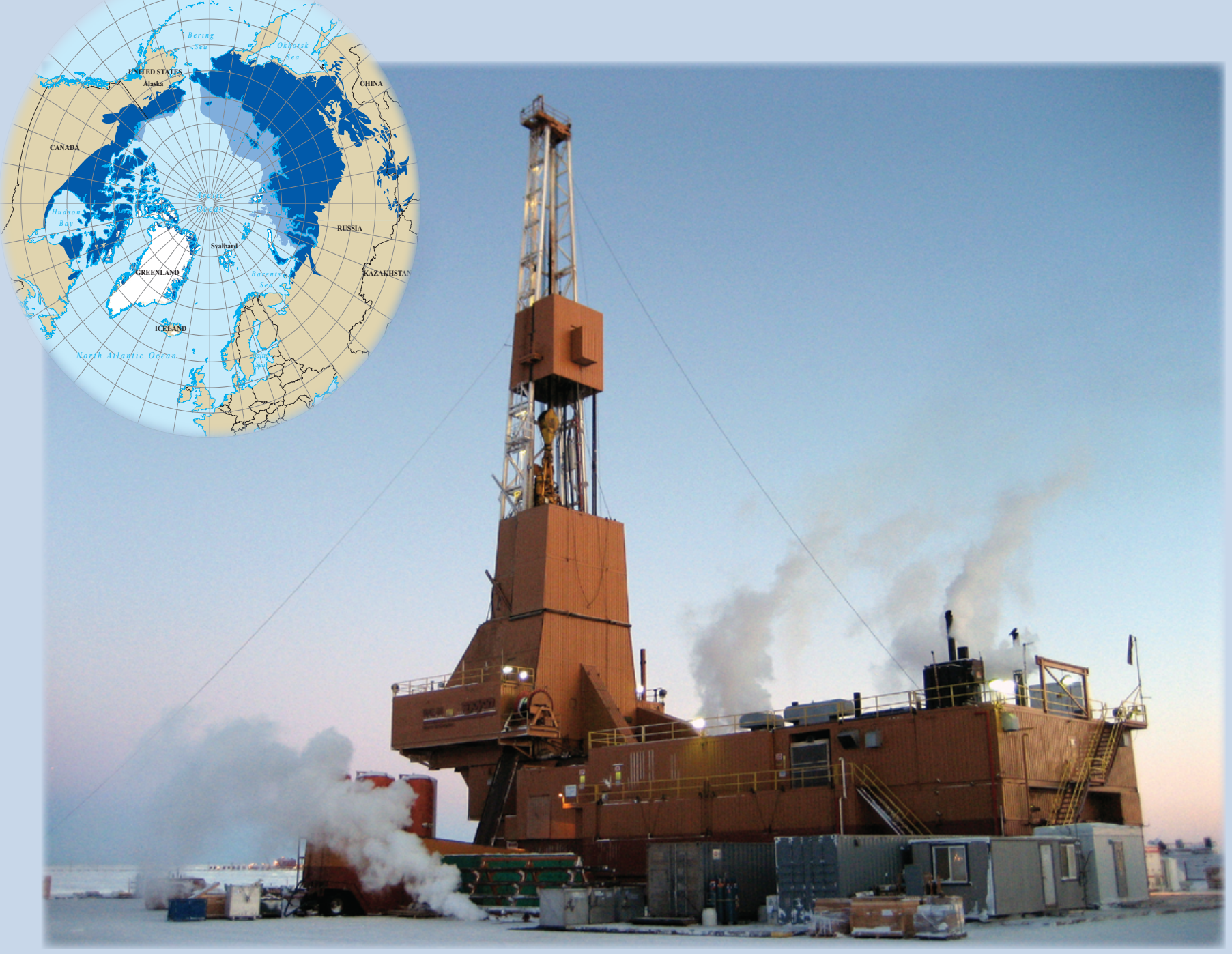

Scientific Investigations Report 2013-5050 
COVER. Part of the Alaska Mount Elbert Stratigraphic Test Well project in 2007 (photo taken by Timothy S. Collett). 


\section{Brookian Sequence Well Log Correlation Sections and Occurrence of Gas Hydrates, North-Central North Slope, Alaska}

By Kristen A. Lewis and Timothy S. Collett

Scientific Investigations Report 2013-5050 


\title{
U.S. Department of the Interior SALLY JEWELL, Secretary
}

\section{U.S. Geological Survey Suzette M. Kimball, Acting Director}

\author{
U.S. Geological Survey, Reston, Virginia: 2013
}

For more information on the USGS - the Federal source for science about the Earth, its natural and living resources, natural hazards, and the environment, visit http://www.usgs.gov or call 1-888-ASK-USGS.

For an overview of USGS information products, including maps, imagery, and publications, visit http://www.usgs.gov/pubprod

To order this and other USGS information products, visit http://store.usgs.gov

Any use of trade, firm, or product names is for descriptive purposes only and does not imply endorsement by the U.S. Government.

Although this information product, for the most part, is in the public domain, it also may contain copyrighted materials as noted in the text. Permission to reproduce copyrighted items must be secured from the copyright owner.

Suggested citation:

Lewis, K.A., and Collett, T.S., 2013, Brookian sequence well log correlation sections and occurrence of gas hydrates, north-central North Slope, Alaska: U.S. Geological Survey Scientific Investigations Report 2013-5050, 23 p., http:// pubs.usgs.gov/sir/2013/5050/. 


\section{Contents}

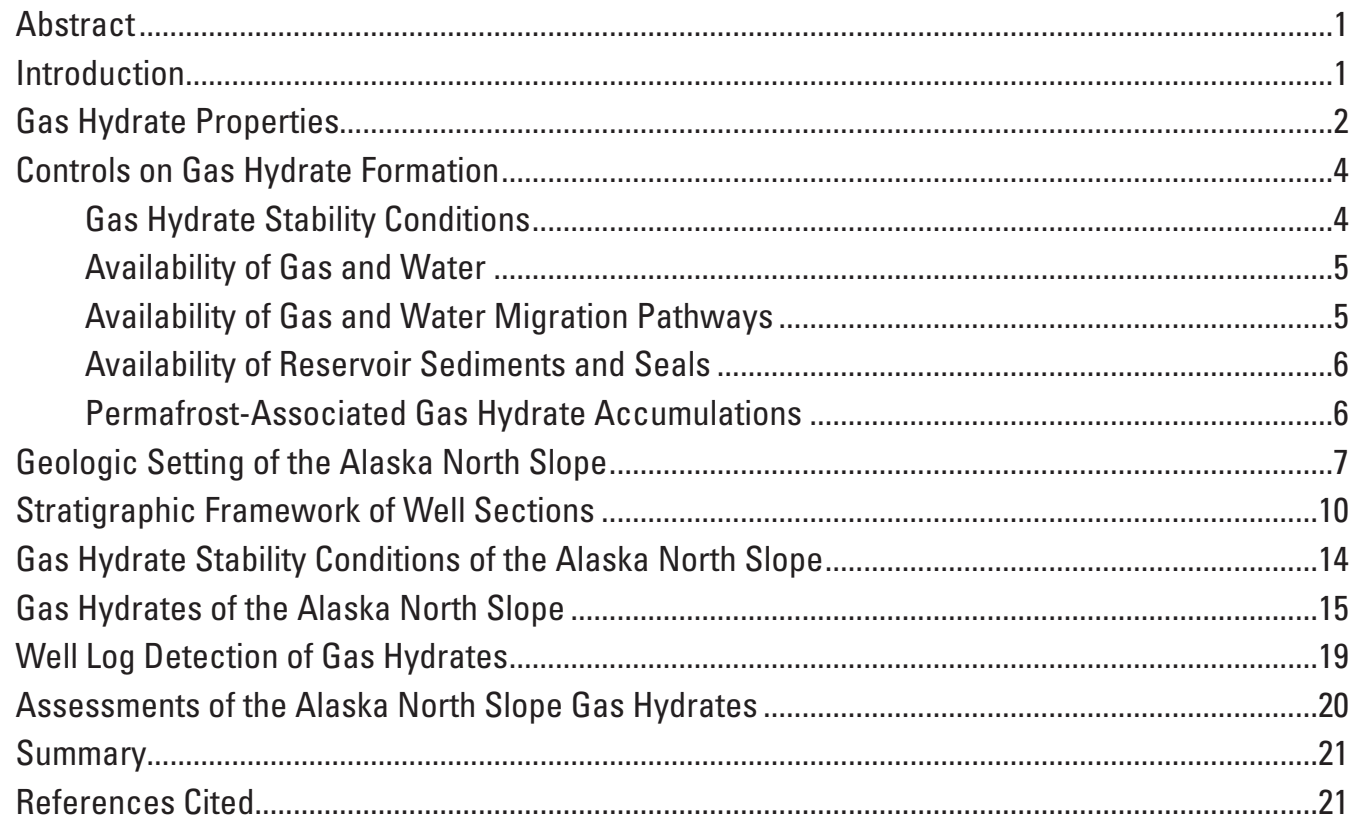

\section{Figures}

1. Locations of known (purple diamonds) and inferred (red circles) gas hydrate occurrences throughout the world

2. Well log correlation section line 1 showing well log markers (C-horizons), gas hydrate picks, gas hydrate stability zone, base of ice-bearing permafrost picks, and $0^{\circ} \mathrm{C}$ markers for wells with map identification numbers 1 through 11

3. Well log correlation section line 2 showing well log markers (C-horizons), gas hydrate picks, gas hydrate stability zone, base of ice-bearing permafrost picks, and $0^{\circ} \mathrm{C}$ markers for wells with map identification numbers 1 and 12 through 24

4. Well log correlation section line 3 showing well log markers (C-horizons), gas hydrate picks, gas hydrate stability zone, base of ice-bearing permafrost picks, and $0^{\circ} \mathrm{C}$ markers for wells with map identification numbers 25 through 33

5. Well log correlation section line 4 showing well log markers (C-horizons), gas hydrate picks, gas hydrate stability zone, base of ice-bearing permafrost picks, and $0{ }^{\circ} \mathrm{C}$ markers for wells with map identification numbers 34 through 54 link

6. Well log correlation section line 5 showing well log markers (C-horizons), gas hydrate picks, gas hydrate stability zone, base of ice-bearing permafrost picks, and $0^{\circ} \mathrm{C}$ markers for wells with map identification numbers 55 through 71 
7. Well log correlation section line 6 showing well log markers (C-horizons), gas hydrate picks, gas hydrate stability zone, base of ice-bearing permafrost picks, and $0{ }^{\circ} \mathrm{C}$ markers for wells with map identification numbers 72 through 93 . link

8. Well log correlation section line 7 showing well log markers (C-horizons), gas hydrate picks, gas hydrate stability zone, base of ice-bearing permafrost picks, and $0{ }^{\circ} \mathrm{C}$ markers for wells with map identification numbers 94 through 107 link

9. Well log correlation section line 8 showing well log markers (C-horizons), gas hydrate picks, gas hydrate stability zone, base of ice-bearing permafrost picks, and $0^{\circ} \mathrm{C}$ markers for wells with map identification numbers 108 through 114 link

10. Well log correlation section line 9 showing well log markers (C-horizons), gas hydrate picks, gas hydrate stability zone, base of ice-bearing permafrost picks, and $0^{\circ} \mathrm{C}$ markers for wells with map identification numbers 115 through 122 link

11. Map of central North Slope showing study wells (green dots), producing oil fields (yellow polygons), known gas hydrate accumulations (orange dashed line), free gas accumulations (green dashed line), and lines of well log correlation sections (red solid lines) in figures $2-10$..

12. Gas hydrate phase diagram showing depth and temperature conditions suitable for gas hydrate formation for various permafrost depths, geothermal gradients, and gas chemistries...... .4

13. Map showing the distribution of permafrost in the northern hemisphere. .7

14. Map of the Alaska North Slope showing the physiographic provinces, major tectonic features, and location of cross section shown in figure 15. . .8

15. Generalized stratigraphic and structural cross section from the Brooks Range to the northern margin of the Beaufort rift shoulder

16. Generalized stratigraphic column for the Alaska North Slope showing the stratigraphic and tectonostratigraphic subdivisions for each of the units

17. Generalized stratigraphic columns for the Colville River Delta, Milne Point, and Prudhoe Bay areas showing the succession of formations from west (left) to east (right)

18. Maps of the Alaska North Slope gas hydrate stability zone ...........................................16

19. Well logs from Northwest Eileen State-2 well.

20. Cross section showing the gas hydrate-bearing units $A$ through $F$ and their relations to the top and base of the gas hydrate stability zone (red and brown dashed lines) and the base of the ice-bearing permafrost (blue dashed line)

21. Schematic cross section through the Prudhoe Bay and Kuparuk River oil fields illustrating possible gas migration pathways (fault zones) and their spatial relations to the Tarn and Eileen gas hydrate accumulations.

\section{Table}

1. Table listing all wells used for well log correlation sections link 


\section{Conversion Factors}

\begin{tabular}{lcl}
\hline \multicolumn{1}{c}{ Multiply } & By & \multicolumn{1}{c}{ To obtain } \\
\hline cubic foot $\left(\mathrm{ft}^{3}\right)$ & Volume & \\
cubic meter $\left(\mathrm{m}^{3}\right)$ & 0.02832 & cubic meter $\left(\mathrm{m}^{3}\right)$ \\
& 35.3147 & cubic foot $\left(\mathrm{ft}^{3}\right)$ \\
\hline foot $(\mathrm{ft})$ & Length & \\
meter $(\mathrm{m})$ & 0.3048 & meter $(\mathrm{m})$ \\
& 3.2808 & foot $(\mathrm{ft})$ \\
\hline kilopascal per meter $(\mathrm{kPa} / \mathrm{m})$ & Pressure & \\
pounds per square inch per foot $(\mathrm{psi} / \mathrm{ft})$ & 0.0442 & pounds per square inch per foot $(\mathrm{psi} / \mathrm{ft})$ \\
& 22.6206 & kilopascal per meter $(\mathrm{kPa} / \mathrm{m})$ \\
\hline square mile $\left(\mathrm{mi}^{2}\right)$ & Area & \\
square kilometer $\left(\mathrm{km}^{2}\right)$ & 2.5900 & square kilometer $\left(\mathrm{km}{ }^{2}\right)$ \\
\hline
\end{tabular}

Temperature in degrees Celsius $\left({ }^{\circ} \mathrm{C}\right)$ may be converted to degrees Fahrenheit $\left({ }^{\circ} \mathrm{F}\right)$ as follows:

${ }^{\circ} \mathrm{F}=\left(1.8 x^{\circ} \mathrm{C}\right)+32$.

Horizontal coordinate information is referenced to the North American Datum of1927 (NAD27).

Concentrations of chemical constituents in water are given in micrograms per liter $(\mu \mathrm{g} / \mathrm{L})$.

\section{Initialisms}

ANS Alaska North Slope

AOGCC Alaska Oil and Gas Conservation Commission

API American Petroleum Institute

EOCU Eocene unconformity

GHSZ gas hydrate stability zone

HRZ highly radioactive zone

IBPF ice-bearing permafrost

LCU Lower Cretaceous unconformity

NPRA National Petroleum Reserve-Alaska

USGS U.S. Geological Survey 



\title{
Brookian Sequence Well Log Correlation Sections and Occurrence of Gas Hydrates, North-Central North Slope, Alaska
}

\author{
By Kristen A. Lewis and Timothy S. Collett
}

\section{Abstract}

Gas hydrates are naturally occurring crystalline, ice-like substances that consist of natural gas molecules trapped in a solid-water lattice. Because of the compact nature of their structure, hydrates can effectively store large volumes of gas and, consequently, have been identified as a potential unconventional energy source. First recognized to exist geologically in the 1960s, significant accumulations of gas hydrate have been found throughout the world. Gas hydrate occurrence is limited to environments such as permafrost regions and subsea sediments because of the pressure and temperature conditions required for their formation and stability. Permafrostassociated gas hydrate accumulations have been discovered in many regions of the Arctic, including Russia, Canada, and the North Slope of Alaska.

Gas hydrate research has a long history in northern Alaska. This research includes the drilling, coring, and well $\log$ evaluation of two gas hydrate stratigraphic test wells and two resource assessments of gas hydrates on the Alaska North Slope. Building upon these previous investigations, this report provides a summary of the pertinent well log, gas hydrate, and stratigraphic data for key wells related to gas hydrate occurrence in the north-central North Slope. The data are presented in nine well $\log$ correlation sections with 122 selected wells to provide a regional context for gas hydrate accumulations and the relation of the accumulations to key stratigraphic horizons and to the base of the ice-bearing permafrost. Also included is a well log database that lists the location, available well logs, depths, and other pertinent information for each of the wells on the correlation section.

\section{Introduction}

Gas hydrates have been identified as a potential unconventional energy resource due to their capacity to store large volumes of natural gas. Gas hydrates are crystalline, ice-like substances that are composed of natural gas molecules, mainly methane, trapped in a solid-water lattice called a clathrate structure. At standard temperature and pressure conditions, one volume of gas hydrate can contain 150 to 180 volumes of methane gas (Collett and others, 2011). It is estimated that the volume of natural gas contained within the world's gas hydrate accumulations exceeds that of known conventional gas resources (Collett, 2002). As a result, interest in the properties of gas hydrates, how they occur in nature, and how to produce them has steadily increased over the years as the world's reliance on natural gas has increased.

First identified in nature in the 1960s (Makogon, 1981), gas hydrates occur in sedimentary deposits throughout the world in limited settings such as permafrost regions and deepmarine environments due to the specific pressure and temperature conditions required for their formation and stability. Figure 1 shows locations of known and inferred gas hydrate occurrences throughout the world.

Gas hydrates located in onshore arctic environments are typically associated with the presence of permafrost because the conditions conducive for the formation of permafrost are similar to those required for gas hydrate formation. Permafrost-associated gas hydrate accumulations appear to develop from existing free-gas accumulations that form in hydrocarbon traps via conventional petroleum system mechanisms, which are subsequently converted to gas hydrate through the onset of cold arctic conditions (Collett, 1993, 2002; Boswell and others, 2011). It is generally believed that the thermal conditions favorable for the formation of permafrost and gas hydrate have persisted in the present-day Arctic since the end of the Pliocene (about 2.588 Ma) (Gradstein and others, 2004; Ogg and others, 2008; Collett and others, 2011). Permafrost-associated gas hydrate accumulations are known or are inferred to exist in the West Siberian Basin and other areas of northern Russia, the Mackenzie Delta and Arctic Islands of Canada, and northern Alaska in the United States (Dallimore and Collett, 2005; Collett and others, 2011).

Gas hydrate research in northern Alaska started in 1972 with the world's first dedicated gas hydrate exploration and test well, the ARCO/Exxon Northwest Eileen State-2 well, drilled in the Prudhoe Bay field (Collett, 1993). Since that time, a number of organizations, especially the U.S. Geological Survey (USGS), have completed numerous research 


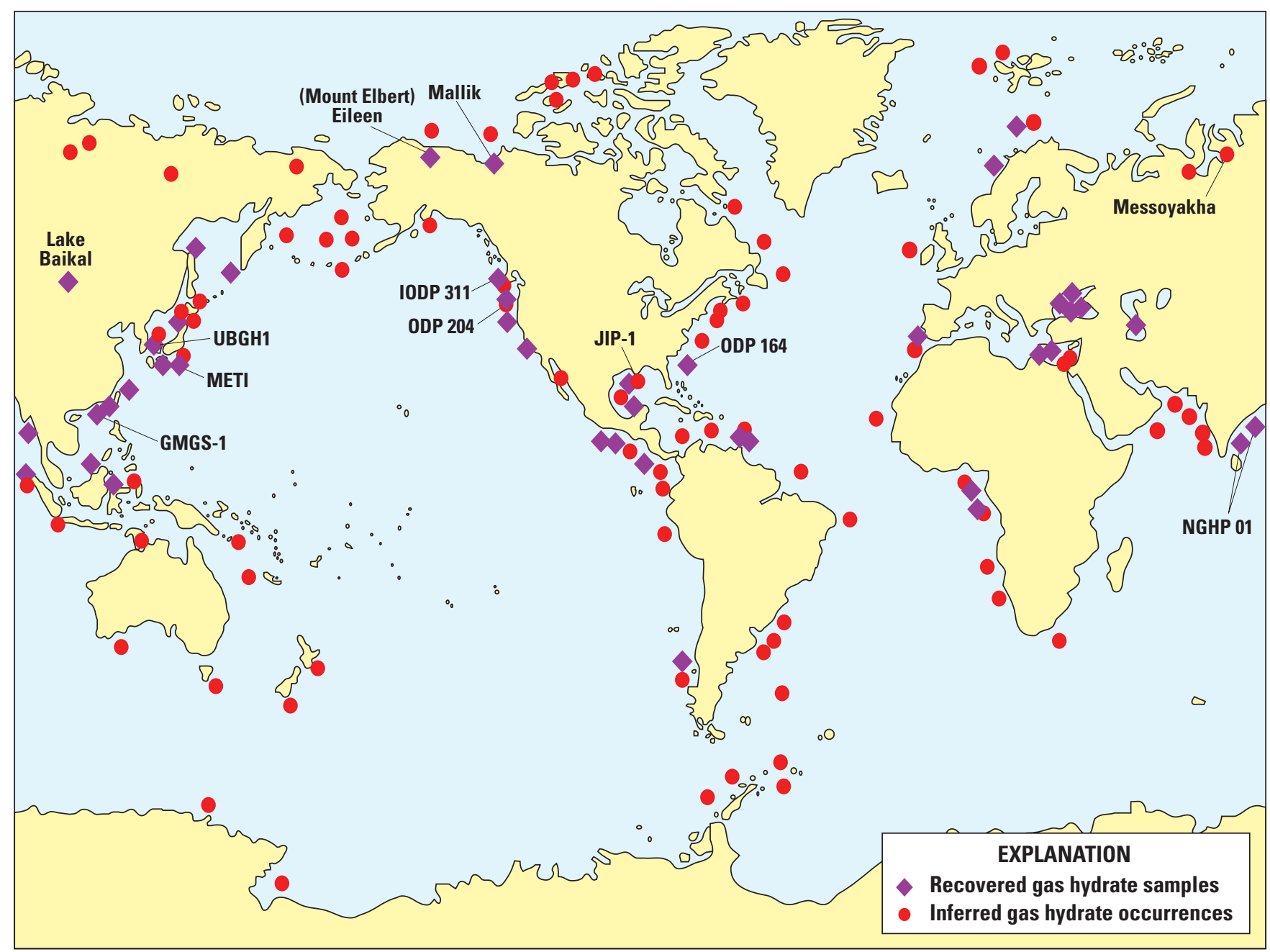

Figure 1. Locations of known (purple diamonds) and inferred (red circles) gas hydrate occurrences throughout the world (modified from Collett, 2002).

investigations focusing on the gas hydrates of the Alaska North Slope. In recent years, these investigations have included the drilling, coring, and logging of the BPXA-DOEUSGS Mount Elbert Gas Hydrate Stratigraphic Test Well (fig. 1) in the Milne Point field in 2007 (Hunter and others, 2011) and the USGS assessment of gas hydrate resources of the Alaska North Slope in 2008 (Collett and others, 2008).

The primary purpose of this report is to provide an overview of the gas hydrate research that has been conducted by the USGS on the North Slope of Alaska. It combines, for the first time, the results of previously published studies (for example, Collett, 1994; Collett and others, 2008; Boswell and others, 2011), existing but unpublished stratigraphic data from well log analyses, and the work of more recent investigations. For this purpose, we present (1) the stratigraphic framework developed by the USGS for investigating gas hydrates in the greater Prudhoe Bay area, as illustrated on nine regional well log correlation sections (figs. 2-10); (2) a tabulated summary of pertinent well data (such as available well logs, key well log markers, tops and bases of gas hydrate-bearing intervals, and the hydrate stability zone) for each of the selected 122 wells used in the construction of the cross sections (table 1); and (3) discussions of the principal stratigraphic units associated with gas hydrate accumulations, general properties of gas hydrates, controls on gas hydrate formation, and the relation between permafrost and gas hydrate accumulation. The wells and cross sections are located between the Sagavanirktok River area in the east to the Colville River area (eastern border of the National Petroleum Reserve-Alaska (NPRA)) in the west, and from the Federal/State offshore boundary in the north to the Meltwater oil field in the south (fig. 11).

\section{Gas Hydrate Properties}

The gas hydrate clathrate structure forms as a threedimensional (3-D) stacking of hydrogen-bonded water molecules that results in an asymmetric, spherical-like "cage" that can hold a single gas molecule (Sloan and Koh, 2008). In 


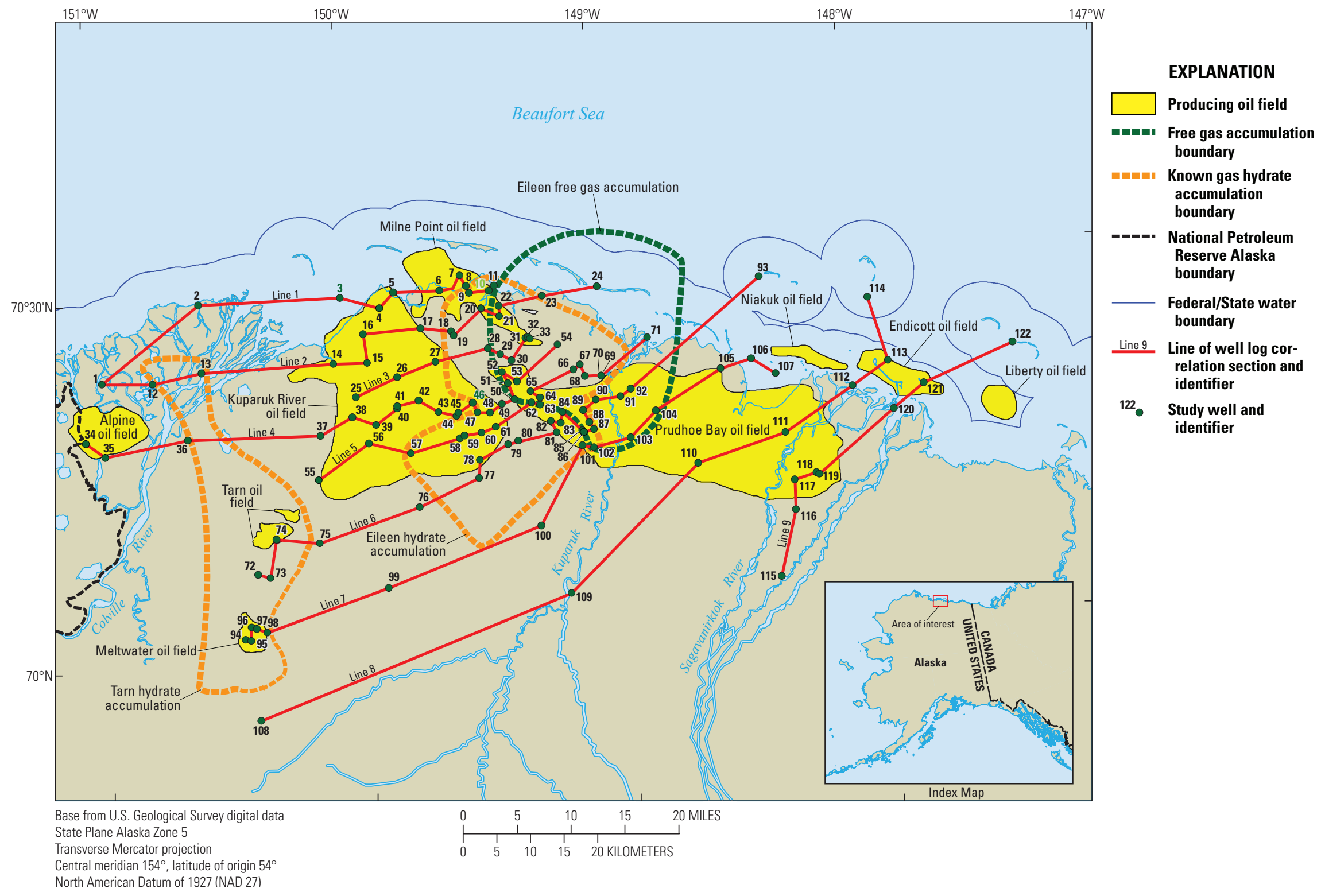

Figure 11. Map of central North Slope showing study wells (green dots), producing oil fields (yellow polygons), known gas hydrate accumulations (orange dashed line), free gas accumulations (green dashed line), and lines of well log correlation sections (red solid lines) in figures 2-10. Numbers listed above each well are the map identification numbers, which correspond to the well numbers listed on each of the well log correlation sections (figs. 2-10). The Federal-State water boundary is indicated by the blue line. Modified from Collett (1993). 
can hold a single gas molecule (Sloan and Koh, 2008). In the case of natural gas hydrates, these encapsulated molecules typically consist of methane, ethane, propane, isobutane, butane, and neopentane. Depending on the types and combinations of molecules contained within the clathrate, different structures of hydrates can form. Because gas hydrates contain approximately 85 -percent water on a molar basis, many of their mechanical properties are similar to those of ice (Collett and others, 2011). For more information about the different types of gas hydrates and their physical properties, refer to the summary given by Sloan and Koh (2008).

In order to estimate the volume of gas hydrate and its associated gas, one must know how gas hydrate forms on the reservoir scale. Gas hydrate accumulations can exist in several different structural forms - disseminated, nodular, layered, and massive - and can occur as inclusions, cement, nodules, laminae, and veins ranging from centimeters to several meters in scale (Collett, 2002). What structural form the gas hydrate accumulation takes and the production potential of the accumulation depends on both the physical and chemical conditions under which the gas hydrate forms. These physical and chemical conditions currently are not well understood; one must rely on descriptions of known gas hydrate accumulations to determine the characteristics of expected gas hydrate accumulations. Characterization of known gas hydrate accumulations is commonly accomplished by drilling, coring, and sampling, but borehole well logs, specifically acoustic sonic, electrical resistivity, and mud logs, also can be used to detect a gas hydrate-bearing unit and to determine its structural form.

\section{Controls on Gas Hydrate Formation}

Although the formation of gas hydrates is not yet completely understood, recent work by Collett and others (2009) and other investigators indicate that using a petroleum system concept, like that used in conventional oil and gas exploration, may also be applicable for gas hydrate resources. These investigations have provided clues about the factors that control the formation and stability of gas hydrate accumulations. According to Collett and others (2011), the most important of these factors are (1) gas hydrate pressure-temperature stability conditions, (2) availability of gas and water, (3) availability of gas and water migration pathways, and (4) suitable reservoir sediment and seals.

\section{Gas Hydrate Stability Conditions}

Gas hydrates can exist only under a limited range of temperature and pressure, called the gas hydrate stability zone (GHSZ). For permafrost-related gas hydrates, the depth and thickness of this zone of potential gas hydrate stability is dependent on several factors including temperature and pressure gradients, gas chemistry, and water salinity. Figure 12 shows a series of gas hydrate temperature-depth plots for several different combinations of subsurface conditions including geothermal gradient, pore pressure, and gas composition (modified from Holder and others, 1987, and as discussed in Collett and others, 2011). Each temperature-depth plot was calculated assuming a mean surface temperature of $-10{ }^{\circ} \mathrm{C}$, whereas the depth to the base of permafrost (that is, $0{ }^{\circ} \mathrm{C}$ isotherm) and the geothermal gradient below permafrost varied for each profile. Permafrost depths of $305 \mathrm{~m}, 610 \mathrm{~m}$, and $914 \mathrm{~m}$ were used, and the geothermal gradients below permafrost were $4.0{ }^{\circ} \mathrm{C} / 100 \mathrm{~m}, 3.2{ }^{\circ} \mathrm{C} / 100 \mathrm{~m}$, and $2.0{ }^{\circ} \mathrm{C} / 100 \mathrm{~m}$, respectively. Additionally, two laboratory-derived hydrate stability curves assuming different gas chemistries, one for a mixture of 98-percent methane, 1.5-percent ethane, and 0.5 -percent propane, and one for 100-percent methane, also are plotted. A hydrostatic pore-pressure gradient of 9.795 kilopascal per meter $(\mathrm{kPa} / \mathrm{m} ; 0.433$ pounds per square inch per foot (psi/ft)) was assumed for the calculations.

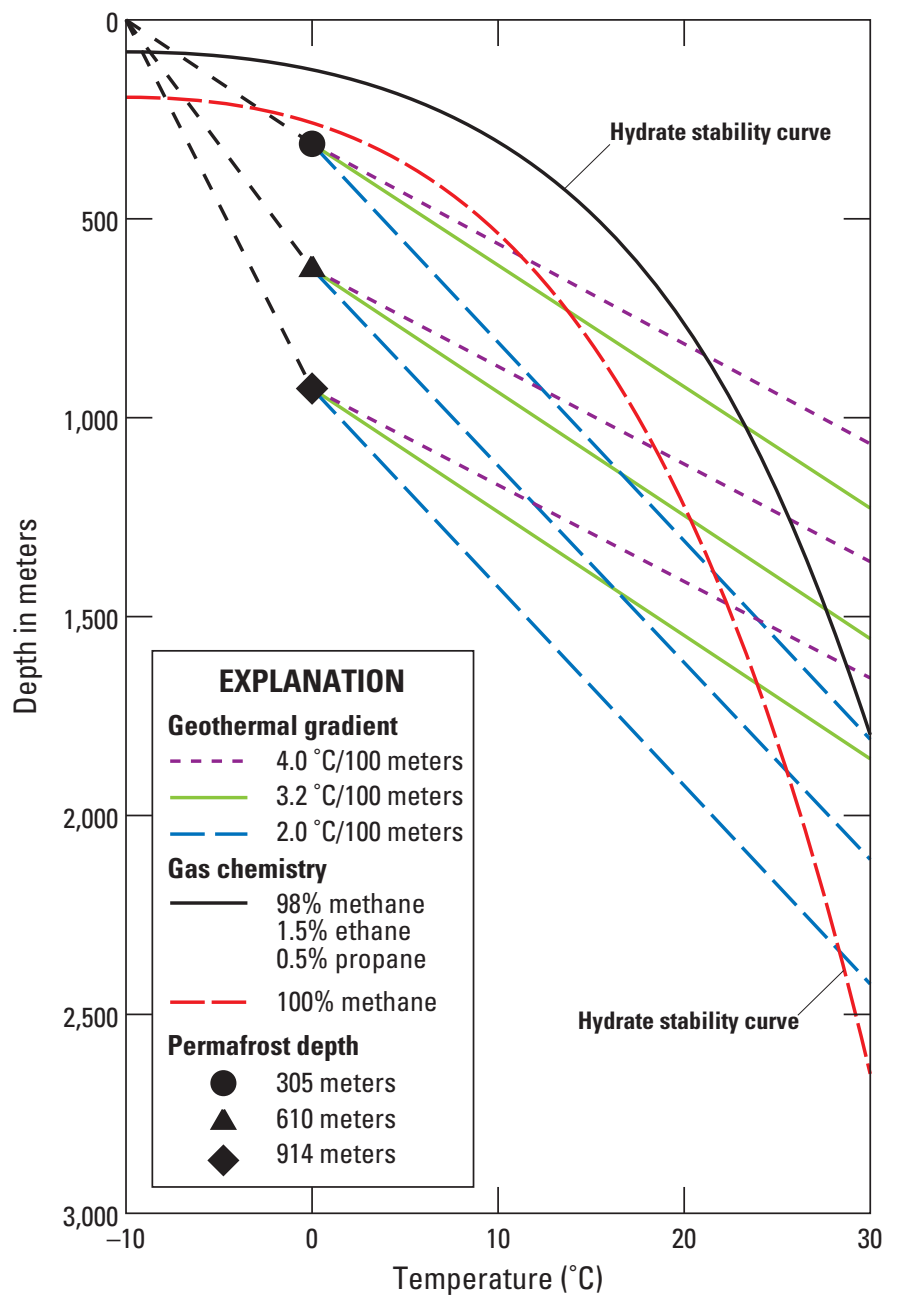

Figure 12. Gas hydrate phase diagram showing depth and temperature conditions suitable for gas hydrate formation for various permafrost depths, geothermal gradients, and gas chemistries (modified from Holder and others, 1987; Collett and others, 2011). A pore-pressure gradient of 9.795 kilopascal per meter was used for all computations. 
In figure 12 , the two hydrate stability curves (indicated by the dashed red and solid black lines) represent the temperatures and depths at which gas hydrates can theoretically exist for the two gas chemistries (that is, the methane-ethane-propane mixture and 100-percent methane). When plotted with the geothermal gradient, the zone of potential gas hydrate stability lies within the depth range between the two points where the geothermal gradient intersects the hydrate stability curve. In the case where the base of permafrost is at a depth of $610 \mathrm{~m}$, the temperature profile first intersects the 100-percent methane hydrate stability curve at approximately $200 \mathrm{~m}$. This represents the top of the GHSZ for a hydrate containing 100-percent methane gas. Assuming a geothermal gradient of $4.0^{\circ} \mathrm{C} / 100 \mathrm{~m}$, the 610 - $\mathrm{m}$ temperature profile also intersects the 100-percent methane hydrate stability curve at a depth of approximately $1,100 \mathrm{~m}$, marking the base of the GHSZ. Thus, for the 610-m temperature profile with a geothermal gradient of $4.0^{\circ} \mathrm{C} / 100 \mathrm{~m}$, the zone of potential hydrate stability extends from a depth of $200 \mathrm{~m}$ to a depth of $1,100 \mathrm{~m}$, resulting in a thickness of $900 \mathrm{~m}$. If, however, the base of the permafrost was deeper at $914 \mathrm{~m}$, the top of the hydrate stability zone would be at approximately $175 \mathrm{~m}$, and the base would be at a depth of $1,450 \mathrm{~m}$, resulting in a GHSZ thickness of approximately $1,275 \mathrm{~m}$.

Further examination of figure 12 indicates that changes in the geothermal gradient and the hydrate gas chemistry also result in variations in the depth and thickness of the GHSZ. If a geothermal gradient of $2.0^{\circ} \mathrm{C} / 100 \mathrm{~m}$ is used for the case in which the base of the permafrost is at $914 \mathrm{~m}$, the hydrate stability zone would extend to a depth of approximately $2,300 \mathrm{~m}$, resulting in a GHSZ thickness of about 2,125 $\mathrm{m}$, an increase of about $850 \mathrm{~m}$ compared to the GHSZ computed with a geothermal gradient of $4.0^{\circ} \mathrm{C} / 100 \mathrm{~m}$. Changing the composition of the gas contained within the gas hydrate also results in changes to the hydrate stability zone. As seen in figure 12, changing the gas composition from 100-percent methane to a mixture of methane, ethane, and propane shifts the hydrate stability curve to the right, extending the GHSZ to greater depths.

Although the geothermal gradient and the composition of the gas contained in the hydrate are the two primary factors that control the GHSZ distribution, other physical and chemical changes can also alter the depth and thickness of the GHSZ. Changing the pore-pressure gradient, either higher or lower than hydrostatic, affects the formation of gas hydrates. In the case that the pore-pressure gradient is higher than hydrostatic, the pore pressures will be greater at depth, which increases the stability of the gas hydrate resulting in a thicker GHSZ (Holder and others, 1987). Conversely, a pore-pressure gradient less than hydrostatic produces lower pore pressures with depth, thereby decreasing the hydrate stability and resulting in a thinner GHSZ. The presence of salt in the gas hydrate system also affects the formation of gas hydrates, in that dissolved salts in the unfrozen pore fluid cause the freezing point of the pore water to lower; hence, the temperature at which the gas hydrate forms is also lower (Holder and others, 1987). This, in turn, causes the hydrate stability curve to shift to the left, thus reducing the thickness of the GHSZ.

\section{Availability of Gas and Water}

Naturally occurring gas hydrates typically form as one of two crystal structure types (Sloan and Koh, 2008). Structure I gas hydrates consist of 46 water molecules that can hold a single, small ( $\leq 5.2$ angstroms) gas molecule such as methane or ethane (Collett, 1994). Structure II hydrates, on the other hand, consist of 136 water molecules and can contain a gas molecule on the order of 5.9 to 6.9 angstroms such as propane or isobutane. The gas molecules contained within the watercrystal structure of the gas hydrate can be biogenic and (or) thermogenic in origin. Although many of the known oceanic hydrate deposits have been determined to contain microbialderived gas, carbon isotope analyses has shown that the majority of the known gas hydrate accumulations in the Prudhoe Bay region of Alaska contain gas that is mostly thermogenic in origin (Collett and others, 2011). With ideal gas-to-water ratios of 8:46 for structure I and 24:136 for structure II, large amounts of both gas and water are required to form gas hydrates (Sloan and Koh, 2008). Thus, large sources of both gas and water are required for gas hydrates to form and, as a result, are important controls on the formation and distribution of gas hydrates in nature.

\section{Availability of Gas and Water Migration Pathways}

Due to the large amount of water and gas needed for gas hydrate formation, efficient mechanisms for both gas generation and migration are required to form large, highly concentrated gas hydrate accumulations. In general, microbial sources cannot generate enough methane internally within the gas hydrate stability zone to form substantial accumulations (Collett and others, 1988; Kvenvolden, 1993a). Likewise, most accumulations are located in sediments that have not been buried deeply enough or subjected to temperatures high enough to form thermogenic gas (Kvenvolden, 1993a; Collett and others, 2011). As a result, the gas contained within the hydrate accumulations was likely generated outside of the GHSZ and was concentrated in the zone through a combination of processes, with gas migration playing a significant role.

Methane within a sedimentary section can migrate by diffusion, advection as a dissolved phase in water, or advection as a gas bubble (Collett and others, 2011). As discussed by Xu and Ruppel (1999), gas migration through diffusion is a slow and inefficient process that is not likely to result in large volumes of gas. Consequently, diffusion is not expected to move enough gas into the GHSZ to produce a concentrated gas hydrate accumulation, so is not anticipated to play a significant role in the production of gas hydrates. With respect to transporting the gas as a dissolved phase in water, Hyndman and Davis (1992) proposed that water, containing a dissolved aqueous phase of methane and possibly other gases, migrates upward into the GHSZ where it encounters conditions of decreasing methane solubility; as a result, the methane 
exsolves and forms gas hydrate. In the case of advection in the gaseous (that is, bubble) phase, gas hydrate forms as the gas bubble migrates upward into the GHSZ and encounters water in the pore space resulting in nucleation of the hydrate at the bubble/pore-water interface (Collett and others, 2011).

Migration of gas through advection as either a dissolved phase in water or in the gaseous phase is a much more efficient process than diffusion and likely plays a significant role in the formation of gas hydrate deposits (Collett and others, 2011). Both advection models require the existence of permeable pathways to permit fluid migration. Typically, these migration pathways consist of porous and permeable sediment layers and (or) fault systems. Without effective migration pathways, significant gas hydrate accumulations cannot develop.

\section{Availability of Reservoir Sediments and Seals}

Although gas hydrates appear in many forms, the most significant deposits have developed in the pores of coarsegrained sediment or as the filling of fractures (Collett and others, 2011), indicating that the accumulation of gas hydrates is likely controlled by the presence of such highly permeable strata that are also associated with effective seals similar to traps for conventional oil and gas reservoirs. In the gas hydrate petroleum system, as in conventional petroleum systems, gas migrates along permeable pathways or faults until it reaches an impermeable seal that prevents the gas from migrating further. Once this gas reaches the seal, it becomes trapped within the porous sediment where it is able to accumulate and concentrate into amounts large enough for gas hydrate formation. Torres and others (2008) concluded that hydrates grow preferentially in coarse-grained sediments because these sediments have lower capillary pressures that permit the gas to enter the pores resulting in the nucleation of the hydrate as the gas contacts the pore water.

\section{Permafrost-Associated Gas Hydrate Accumulations}

Based on known accumulations, gas hydrates in the onshore environment appear to be closely linked to the presence of permafrost, the formation and distribution of which are influenced by climatic conditions. Specifically, the formation of permafrost is dependent on the near-surface ground temperature and the geothermal gradient (Ferrians, 1994) - the lower the near-surface temperature and the geothermal gradient, the thicker the permafrost zone. If adequate conditions persist, permafrost can grow to be hundreds of meters thick over a period of thousands of years. However, if surface temperatures change, such as during periods of transgressing or regressing seas, the distribution and thickness of the permafrost can be affected (Ferrians, 1994).

Maps of the present-day distribution of permafrost show that approximately 20 percent of the land area of the northern hemisphere contains permafrost (Ferrians, 1994; Collett and others, 2011) (fig. 13). Current climate models suggest that the present-day Arctic has had thermal conditions conducive to the formation of permafrost and gas hydrate since the end of the Pliocene, about 2.588 Ma (Gradstein and others, 2004; Ogg and others, 2008; Collett and others, 2011). During this time, the Arctic Ocean continental shelf was subaerially exposed to current water depths of $120 \mathrm{~m}$ (Bard and Fairbanks, 1990). Concurrent with this emergence, periodic episodes of glaciation also occurred exposing the Arctic continental terrain and shelf to conditions favorable for the formation of permafrost and gas hydrates (Osterkamp and Fei, 1993). These periods of glaciation and their associated reduction in temperature likely caused the sediments, pore water, and any pre-existing freegas accumulations in the shallow subsurface to form permafrost and associated gas hydrate accumulations (Collett, 1993; Collett, 2002; Boswell and others, 2011; Collett and others, 2011).

During the interglacial periods, sea-level rises subjected the Arctic continental shelf to warmer temperature conditions, possibly causing thawing of permafrost and destabilization of gas hydrates. Although the upper portion of the permafrost responds quickly to changes in the surface temperature, deeper portions of the permafrost may require centuries before the warm surface temperatures cause thawing (Osterkamp and Fei, 1993; Ferrians, 1994). Consequently, it is speculated that relic permafrost and gas hydrate may still exist on the Arctic continental shelf (Osterkamp and Fei, 1993), possibly to present-day water depths of $120 \mathrm{~m}$ (Collett and others, 2011). Although permafrost has been documented on the present-day continental shelf (for example, Molochushkin, 1973), analysis of log data from industry exploratory wells suggests that the occurrence of this relic permafrost and gas hydrate may be limited to present-day water depths of $50 \mathrm{~m}$ or less (Collett and others, 1988; Collett and others, 2011). This observed limit, however, is not consistent with the modeling of Osterkamp and Fei (1993) and may simply be a consequence of the limited number of direct permafrost measurements available.

At present, permafrost-associated gas hydrates are known to exist in the Arctic regions of Russia, Canada, and northern Alaska. Onshore gas hydrates have been confirmed to exist in the West Siberian Basin of Russia and also are thought to exist in other permafrost regions (Kvenvolden, 1993b; Collett, 2002; Collett and others, 2009). In Canada, permafrostassociated gas hydrates have been detected in approximately one-fifth of the wells drilled in the Mackenzie Delta and more than half of the wells drilled in the Arctic Islands of Canada (Judge and others, 1994; Osadetz and Chen, 2005). Two wells drilled on the Alaska North Slope provide direct evidence of gas hydrate existence in northern Alaska (Collett and others, 2011). Based on the characteristics of these known accumulations, permafrost-related gas hydrates appear to exist from subsurface depths of approximately 150 to $2,000 \mathrm{~m}$ (500 to $6,500 \mathrm{ft}$ ) worldwide and, more specifically, from approximately 150 to $1,200 \mathrm{~m}$ (500 to 4,000 ft) on the Alaska North Slope (Collett and others, 2011). 


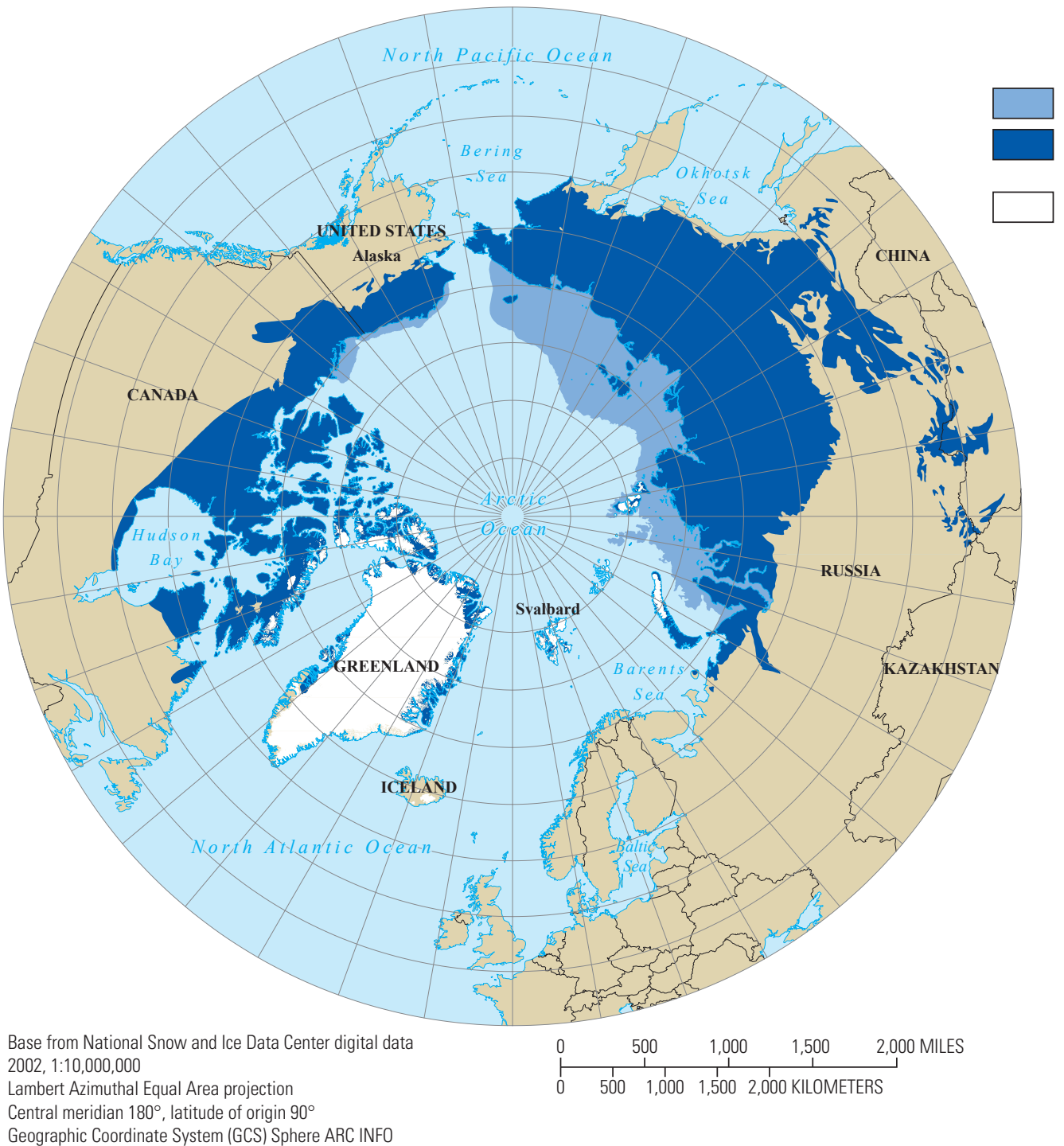

EXPLANATION

Offshore relic permafrost

Continuous permafrost-National Snow and Ice Data Center

Greenland ice sheet-National Snow and Ice Data Center

Figure 13. Map showing the distribution of permafrost in the northern hemisphere (source of data: http://nsidc.org/data/ggd318.htm/). Highlighted are the areas of onshore continuous permafrost (dark blue) and the possible offshore relic permafrost (light blue) where conditions may be favorable for the accumulation of permafrost-related gas hydrates (modified from Brown and others, 2002; Collett, 2002; Collett and others, 2011).

\section{Geologic Setting of the Alaska North Slope}

The Alaska North Slope (ANS), one of the most prolific petroleum provinces in the United States, is defined as the region extending from the Brooks Range drainage divide northward to the continental shelf and from the Chukchi Sea eastward to the U.S.-Canadian border (fig. 14). The northsouth extent of the ANS ranges from approximately 100 to $600 \mathrm{~km}$ and extends approximately $950 \mathrm{~km}$ in the east-west direction (Bird, 2001; Collett and others, 2011). A geologically complex region, the ANS can be subdivided into three physiographic provinces, from north to south: the coastal plain, foothills, and Brooks Range provinces (fig. 14). These provinces are oriented in a roughly east-west direction and represent divisions not only of the surface topography but also of the underlying geologic trends.

The major onshore structural features of the region consist of the Barrow arch, the Colville foreland basin, and the Brooks Range orogenic belt (fig. 14). During the Jurassic to Early Cretaceous, the Arctic Alaska microplate rifted from the Canadian Arctic margin forming the Canadian Basin and also resulting in the development of the Beaufort rift shoulder (Bird and Houseknecht, 2011) (fig. 15). The Beaufort rift shoulder is defined as the generally southward dipping acoustic basement that underlies Arctic Alaska and the Chukchi shelf, with the 


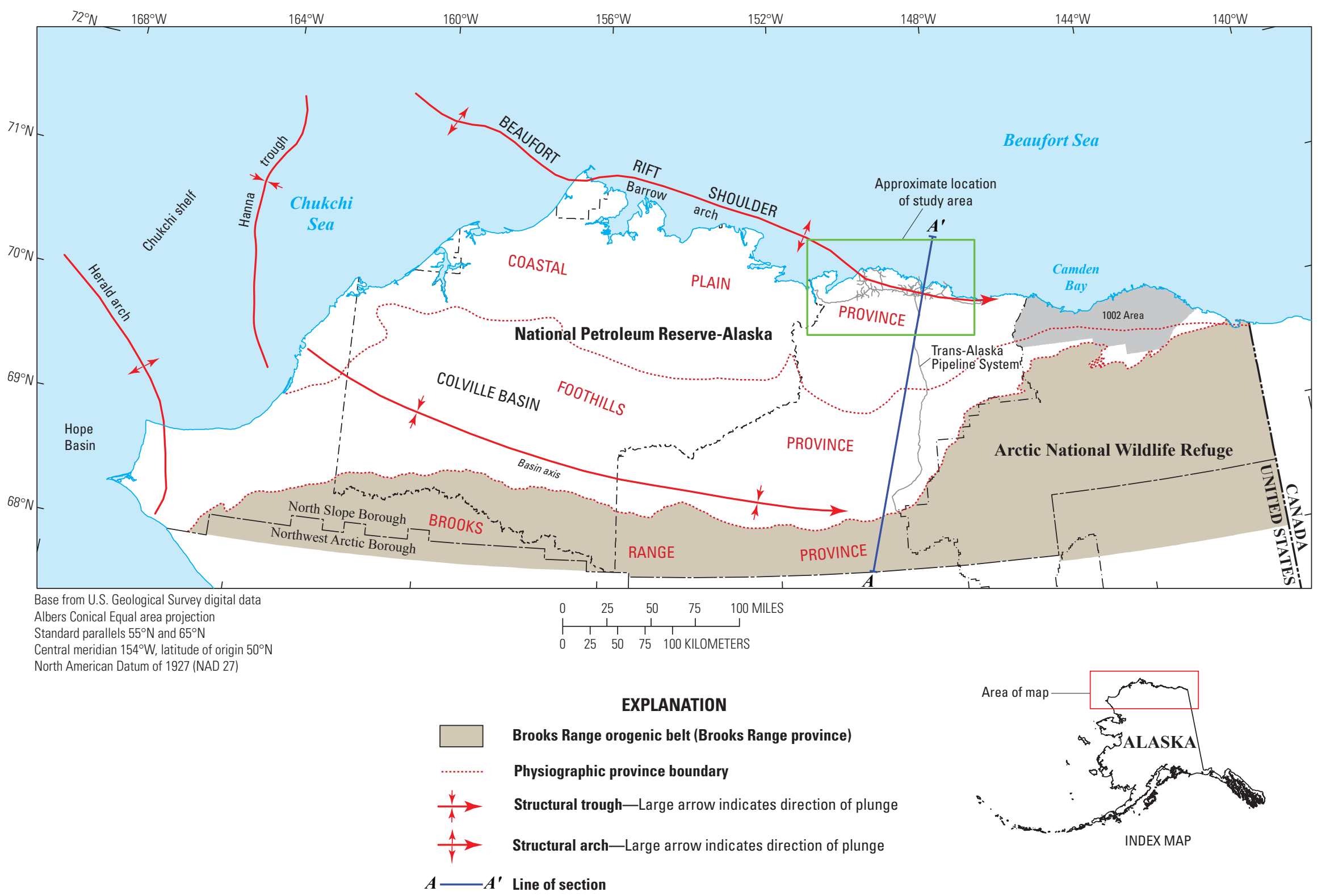

Figure 14. Map of the Alaska North Slope showing the physiographic provinces, major tectonic features, and location of cross section shown in figure 15 (modified from Collett and others, 2011). Blue line indicates figure 15 cross-section location. 
KILOMETERS

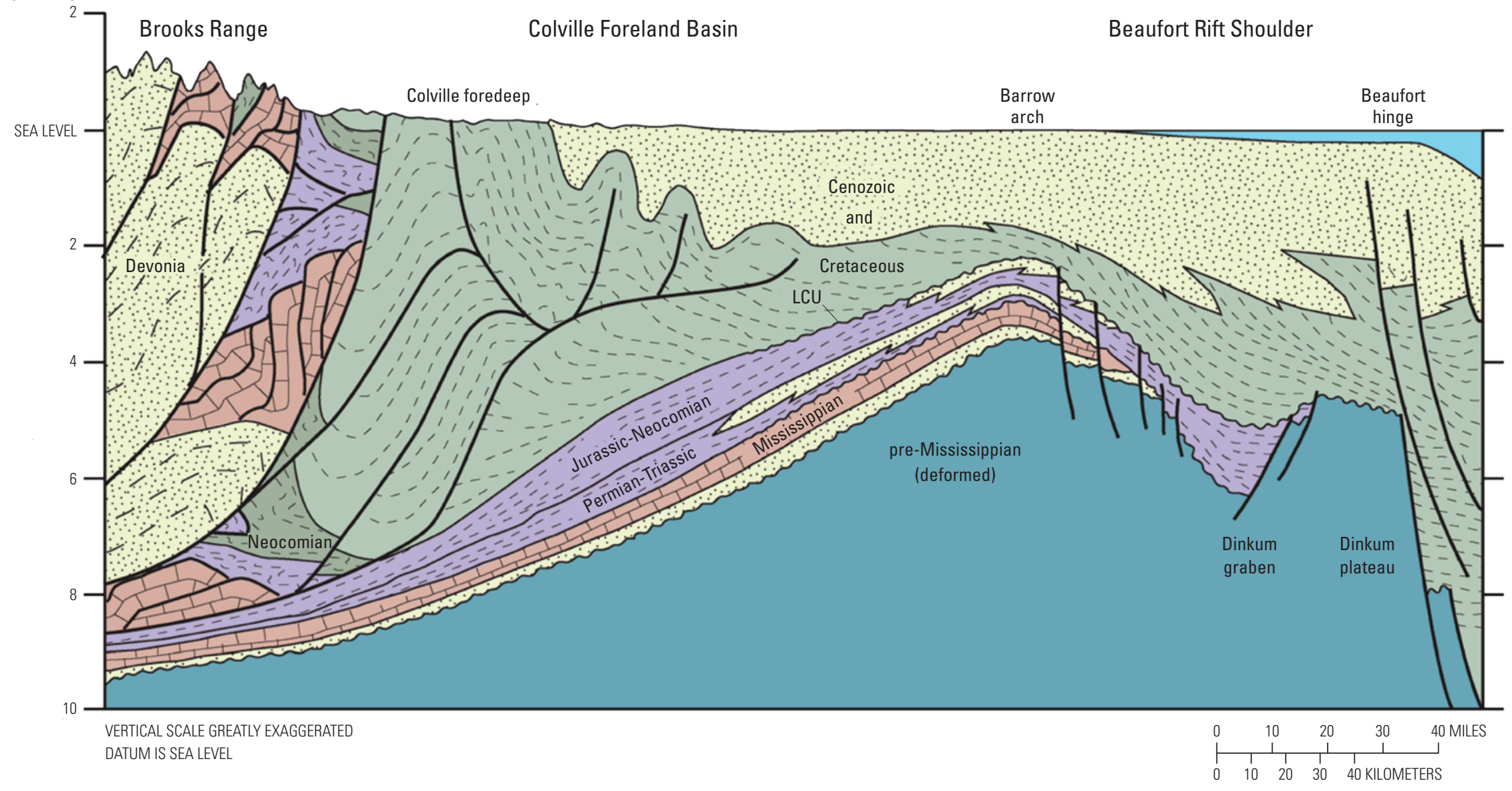

Figure 15. Generalized stratigraphic and structural cross section from the Brooks Range to the northern margin of the Beaufort rift shoulder (Bird and Houseknecht, 2011). Location of cross section shown in figure 14. LCU, Lower Cretaceous unconformity. 
Barrow arch defined as the crest of the rift shoulder (Bird and Houseknecht, 2011) (fig. 15). The Barrow arch separates the Colville foreland basin from the present-day Arctic Ocean basin (Bird, 2001; Collett and others, 1988). Concurrent with this period of rifting, the Brooks Range orogenic belt, Colville foreland basin, and the Herald arch orogenic belt formed due to an arc-continent collision at the southern margin of the Arctic and Chukchi platforms (Bird, 2001). At present, the basement slopes southward from the Barrow arch reaching depths on the order of 10,000 $\mathrm{m}$ along the axis of the Colville foreland basin (that is, Colville trough) (Collett and others, 1988; Bird and Houseknecht, 2011).

The sedimentary rocks of the North Slope can be divided into four tectono-stratigraphic sequences, from oldest to youngest: the Franklinian, Ellesmerian, Beaufortian, and Brookian (fig. 16). Franklinian strata are Devonian and older and include rocks of both sedimentary and igneous origin. Due to their complex geologic history, knowledge about the Devonian rocks is rather limited, but it is commonly accepted that they have been buried and metamorphosed to temperatures that were greater than the threshold for oil preservation (Bird, 2001). Consequently, the Devonian sequence rocks are considered the economic basement for the North Slope Basin.

The Ellesmerian sequence includes rocks that are Mississippian through Triassic age and consist of mainly nonmarine to shallow marine siliciclastic deposits and carbonates that formed as continental shelf deposits on a passive margin (Bird, 2001). Oil production from the Ellesmerian sequence is from the Endicott, Lisburne, and Sadlerochit Groups.

The Beaufortian sequence ranges in age from Jurassic to Early Cretaceous and was deposited during a period of rifting (Bird, 2001). The sequence consists mainly of marine shale with some shallow marine sands and shelf to slope mudstones and siltstones. Due to the rift-related uplift, a period of erosion occurred that produced a regional erosional unconformity called the Lower Cretaceous unconformity (LCU). The LCU progressively truncates older rocks in the northward direction (Houseknecht and Bird, 2006). Subsequent to this uplift and erosion, there was a period of subsidence and marine transgression along the rift margin resulting in an areally extensive marine mudstone/shale unit (Bird, 2001), the Pebble shale unit, which marks the end of the Beaufortian sequence.

The Brookian sequence consists of deposits formed from the Cretaceous through the present that were, and are, derived from detritus supplied, in part, by the Brooks Range orogen (Bird, 2001). During the period of uplift that formed the Brooks Range, regional subsidence occurred immediately to the north of the Brooks Range and formed the Colville foreland basin. Cretaceous and Tertiary sediments filled the Colville foreland basin, overtopped the rift shoulder, and subsequently formed the present-day passive margin north of Alaska (Bird, 2001). Sediment fill of the Colville foreland basin generally progressed from west to east during this period. The Brookian sequence (fig. 16) contains both source and reservoir rocks and consists of a number of different siliciclastic deposits including condensed marine shale (Hue
Shale), marine shale turbidites (Torok, Seabee, and Canning Formations), and shallow marine and nonmarine deposits (Nanushuk, Tuluvak, Schrader Bluff, Prince Creek, and Sagavanirktok Formations). The Hue Shale is an important oil source rock, whereas the Brookian mudstones may serve as a source of gas (Houseknecht and Bird, 2006). The lower portion of the Hue Shale contains a zone with highly radioactive material that is referred to as the highly radioactive zone (HRZ). Due to the radioactive nature of the sediments in this zone, the $\mathrm{HRZ}$ is also characterized by high gamma ray counts and is easily detected with gamma ray logging tools. As a result, the HRZ is also commonly called the gamma ray zone.

Two other informally defined stratigraphic units in the Brookian sequence, commonly referred to as the West Sak and Ugnu sands, are present in the Kuparuk River oil field area (fig. 11). The West Sak sands are equivalent in age to the upper portion of the Schrader Bluff Formation, and the Ugnu sands are equivalent in age to the lower portion of the Prince Creek Formation (fig. 16). Although Jamison and others (1980) formally defined the West Sak stratigraphic unit, other authors have defined it and the Ugnu sand differently throughout the years. Use of these informal terms is limited to the definition applied by Werner (1987) for this report, but the formally defined units Schrader Bluff and Prince Creek Formations are preferred (following Mull and others, 2003).

\section{Stratigraphic Framework of Well Sections}

The nine well log correlation sections (figs. 2-10) show the regional stratigraphic relations of gas hydrate-bearing strata and associated rocks that compose the sedimentary sequence lying above the Lower Cretaceous unconformity across north-central Alaska (figs. 11 and 17). Table 1 lists detailed information on each of the wells numbered 1-22 used for constructing the sections, and the numbers are crossreferenced with the individual wells on the sections.

Nineteen well log markers were identified and picked based on both natural gamma ray and electrical resistivity well logs in order to gain a better understanding of the stratigraphic framework in the study area. The well log markers, also referred to as the $\mathrm{C}$ horizons in this report, represent significant lithologic changes (that is, mainly flooding surfaces) that are easily identifiable from their well log responses and are laterally extensive in the study area. The nineteen marker horizons are also roughly equivalent to those presented in Collett and others (1988). In order to maintain consistency, the marker horizons presented in this report utilize the same naming convention as given in Collett and others (1988), even though that publication included an additional three log markers $(\mathrm{C} 2-\mathrm{C} 4)$. For the Cretaceous and Tertiary stratigraphic section, the terminology, divisions, and ages of Mull and others (2003) are used. 
Geologic Time

Tectono-Stratigraphic Sequences

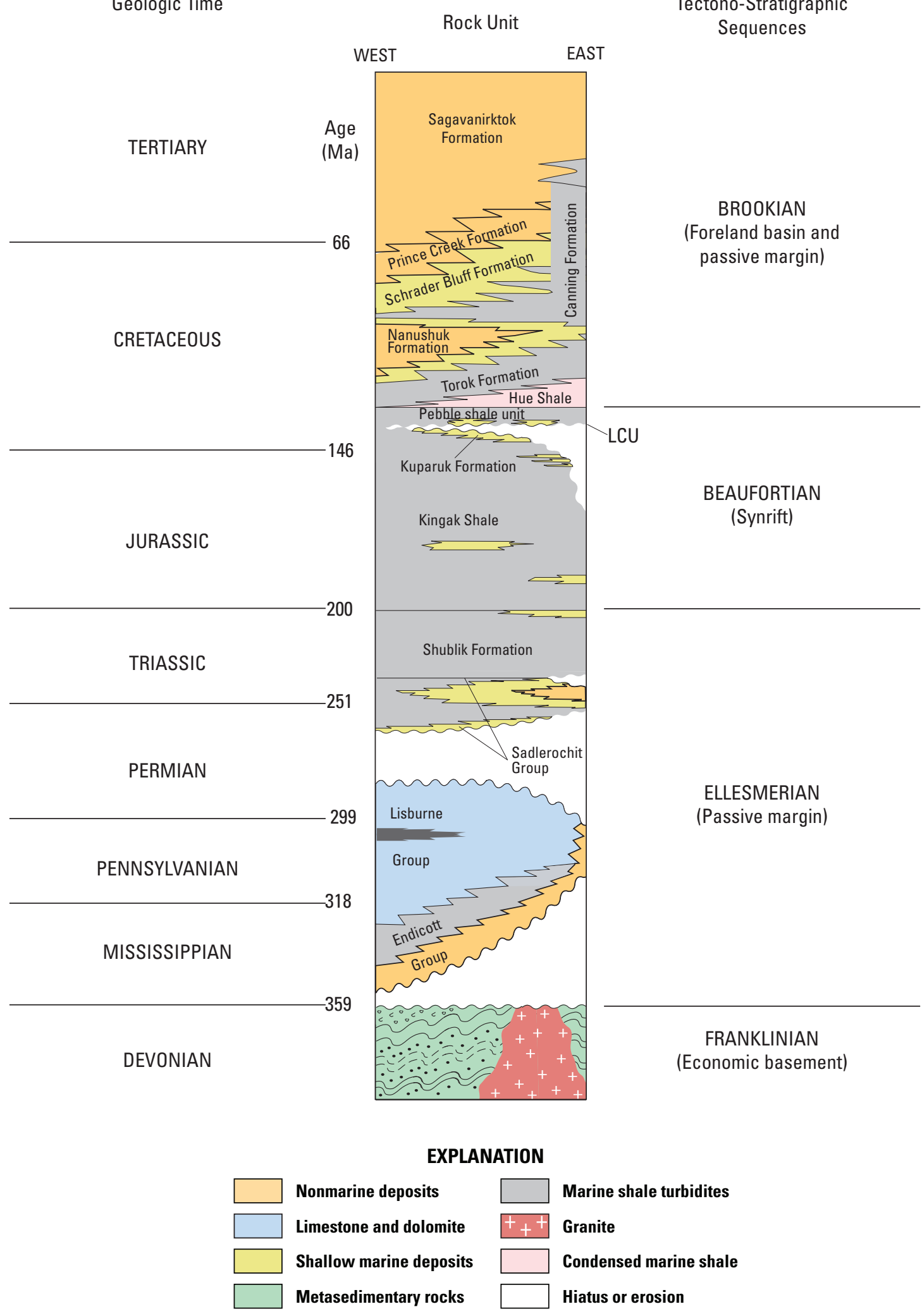

Figure 16. Generalized stratigraphic column for the Alaska North Slope showing the stratigraphic and tectono-stratigraphic subdivisions for each of the units (modified from Collett and others, 2011; Bird, 2001). LCU = Lower Cretaceous unconformity. 


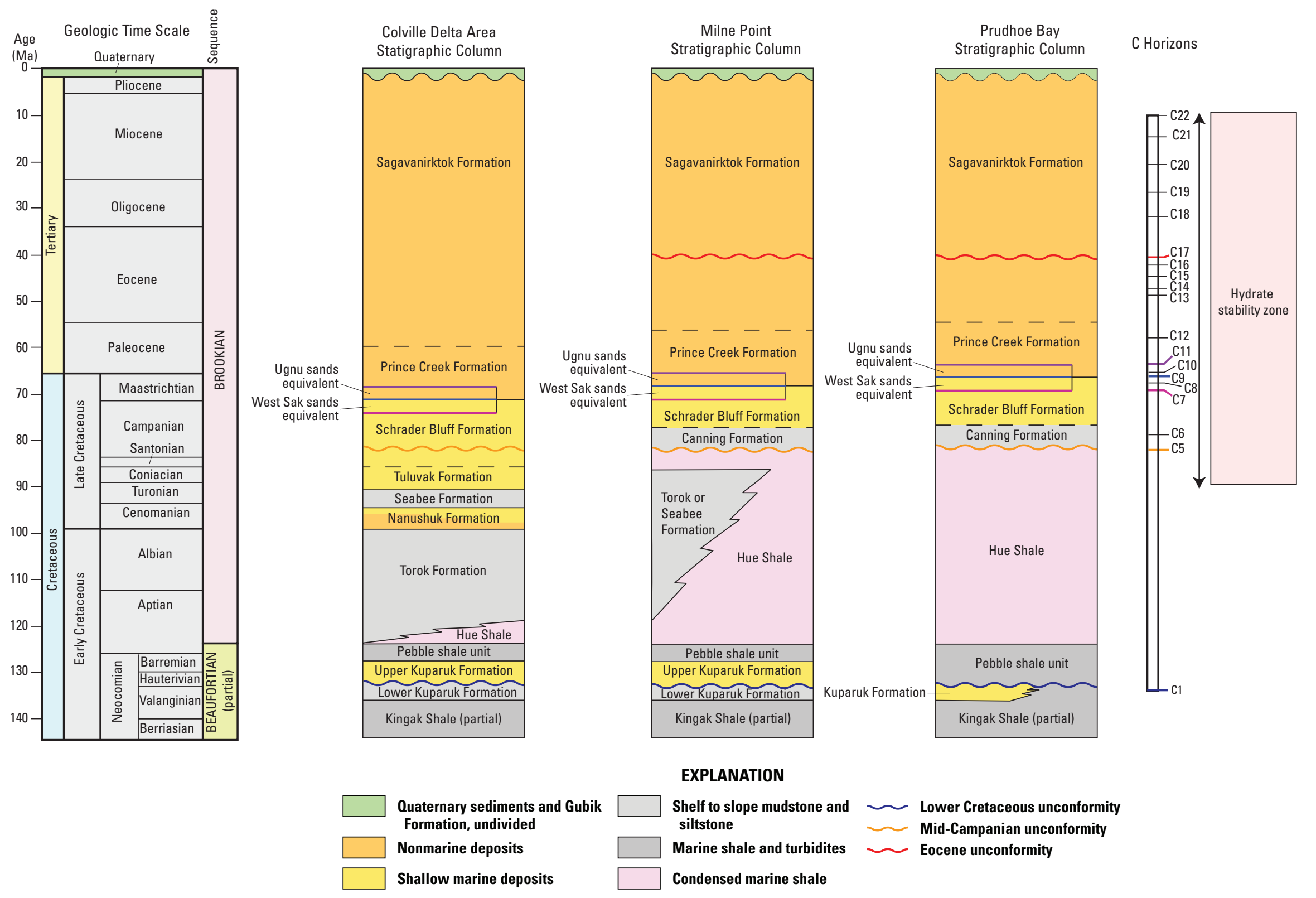

Figure 17. Generalized stratigraphic columns for the Colville River Delta, Milne Point, and Prudhoe Bay areas showing the succession of formations from west (left) to east (right). The C-horizons are also plotted to show their relation to the various formations. The key C-horizons (as discussed in the text) and the gas hydrate stability zone are also highlighted. Ages are from the international stratigraphic chart as compiled by the International Commission on Stratigraphy (http://www.stratigraphy.org) and as originally compiled from Gradstein and others (2004) and Ogg and others (2008). 
The LCU is a regional erosional unconformity (denoted as marker $\mathrm{C} 1$ on the correlation sections) that exists throughout the study area. For this report, the LCU/C1 marker shown in figures 2-10 was picked utilizing an unpublished USGS Alaska formation "tops file" that contains a listing of the depths of all the major geologic "markers" and formation tops penetrated in approximately 400 wells as of December 1, 1998. As shown in figure 17, the LCU truncates different formations depending on the geographic location. From the eastern part of NPRA to the Milne Point area, the LCU truncates part of the Lower Cretaceous Kuparuk Formation, resulting in the upper portion of the formation unconformably overlying the lower portion of the formation and with the Pebble shale unit conformably overlying the upper Kuparuk Formation. Farther to the east, however, the LCU truncates the upper portion of the Kuparuk Formation, which is then unconformably overlain by the Lower Cretaceous Pebble shale unit (fig. 17). As discussed previously, the Pebble shale unit is an areally extensive marine mudstone/shale unit deposited as a result of a marine transgression and marks the end of the Beaufortian sequence.

All of the rocks above the Pebble shale unit belong to the Brookian sequence and are partially derived from sediments produced as a result of the Brooks Range orogeny. Conformably overlying the Pebble shale unit is the Lower to Upper Cretaceous Hue Shale, a condensed marine shale (fig. 17). Molenaar and others (1987) defined the base of the Hue Shale to be the base of the bentonitic shale that separates it from the nonbentonitic shale of the Pebble shale unit. Due to the organic content in the bentonitic shale, the lower portion of the Hue Shale is highly radioactive and has been designated as the highly radioactive zone or HRZ.

In the western portion of the study area, the Hue Shale is overlain by the slope to shelf mudstones and siltstones of the Aptian to Cenomanian Torok Formation (fig. 17). The Torok Formation, in turn, coarsens upward into the interbedded shallow marine and nonmarine sandstone and shale of the Nanushuk Formation (Albian to Cenomanian). The Torok and Nanushuk Formations are both part of a large northeasterly prograding sequence; consequently, the formations thin and pinch out toward the northeast (fig. 17; Houseknecht and others, 2009). The Torok and Nanushuk Formations represent the coeval lower and upper parts of a prograding clastic wedge (Mull and others, 2003).

The Nanushuk and Torok strata are overlain by the Seabee (Cenomanian to Coniacian) and Tuluvak (Turonian to Coniacian) Formations. Following the terminology of Mull and others (2003), the lowest section of the Seabee Formation consists of a series of mudstones, shales, and tuff beds that conformably overlie the Nanushuk Formation and represents a major transgressive marine flooding surface. The remainder of the Seabee, together with the Tuluvak Formation, forms a genetic couplet representing a progradational depositional environment, with the Seabee consisting of shelf to slope mudstones and siltstones and marine shales and turbidites and the Tuluvak consisting of nonmarine to shallow marine conglomerates and sandstones (Decker, 2007). The top of the Seabee Formation interfingers with the sediments of the lower Tuluvak Formation. Although not well exposed in outcrop, the top of the Tuluvak Formation is believed to be gradational and likely interfingers with the base of the Schrader Bluff Formation (Decker, 2007). Progressing eastward, the Torok, Nanushuk, Seabee, and Tuluvak Formations all thin and pinch out (fig. 17). In some places near the Milne Point area (fig. 11), the Torok Formation still overlies the Hue Shale, but the Nanushuk, Tuluvak, and possibly Seabee Formations have pinched out.

The Schrader Bluff (Santonian to Maastrichtian) and Prince Creek Formations (Campanian to Paleocene), along with the Canning Formation (Santonian to Campanian) and Hue Shale appear to be a series of genetically related formations that represent a period of large-scale progradation during Late Cretaceous to Paleocene time (Decker, 2007). Based on regional relations, this progradation appears to have advanced in a northeasterly direction (Mull and others, 2003). The Schrader Bluff and Prince Creek Formations are typically considered to be a genetic couplet with the two formations being differentiated based on depositional environment. The Schrader Bluff consists of shallow marine to shelf deposits, whereas the Prince Creek consists of nonmarine deposits. Using the terminology of Mull and others (2003) and Decker (2007), the Canning Formation represents the equivalent slope facies to the Schrader Bluff and Prince Creek Formations and, therefore, is the basinward extension of the progradation. In the study area, Campanian strata are incised by an areally extensive mass-wasting or erosional surface. This surface, referred to as the mid-Campanian unconformity by Decker (2007), has incised portions of the Schrader Bluff, Tuluvak, and Seabee Formations, and Hue Shale and is approximately equivalent to marker $\mathrm{C} 5$ on the well log correlation sections. For some wells, a distinct break appears on the gamma ray log within the Canning Formation, which may represent a basinwide marine transgression. This break is identified as marker C6 on the well correlation sections (fig. 17).

Within the Schrader Bluff and Prince Creek Formations, a series of laterally persistent markers were identified on the gamma ray logs (markers $\mathrm{C} 7$ through $\mathrm{C} 12$ ). Four of these markers $(\mathrm{C} 7, \mathrm{C} 9, \mathrm{C} 10$, and $\mathrm{C} 11)$ are believed to be roughly equivalent to the base of the West Sak, top of the West Sak, base of the Ugnu, and top of the Ugnu, respectively (fig. 17). For this study, however, these markers were picked based solely on the log character, and they correspond to the approximate tops and bases of the West Sak and Ugnu as defined by Werner (1987).

Continuing up the stratigraphic section, the Paleocene to Pliocene(?) Sagavanirktok Formation overlies the Prince Creek Formation (fig. 17). As defined by Mull and others (2003), the Sagavanirktok Formation consists of a series of three northeasterly prograding sequences that are grouped into four members: the Sagwon (upper Paleocene), White Hills (upper Paleocene? to lower Eocene), Franklin Bluffs (lower Eocene to Miocene), and Nuwok (Miocene? to Pliocene?) 
Members. The Sagavanirktok Formation (undifferentiated) is predominantly nonmarine but does contain some interfingering of nearshore marine clastic rocks (Mull and others, 2003; Decker, 2007). Because both the Prince Creek and Sagavanirktok Formations consist mainly of nonmarine strata, the boundary between them is not well defined, and, as Decker (2007) pointed out, the contact separating the two nonmarine sections is difficult to recognize based on well logs alone. As a consequence, the boundary separating the Prince Creek and Sagavanirktok Formations is denoted with a dashed line in figure 17.

Within the Sagavanirktok Formation, a series of laterally persistent markers were identified on the gamma ray logs (markers $\mathrm{C} 13$ through $\mathrm{C} 22$ ). The rock units represented by markers $\mathrm{C} 13$ to $\mathrm{C} 17$ are characterized by a series of coarsening-upward and fining-upward nonmarine and nearshore marine sandstone and siltstone sequences. The marine strata within the section from $\mathrm{C} 13$ through $\mathrm{C} 17$ likely were deposited during a basinwide transgression that occurred during the Eocene (Collett and others, 1988). In the Prudhoe Bay-Kuparuk River area, this section is cut by an erosional unconformity (marker C17; fig. 17), called the Eocene unconformity (EOCU), that appears to be the erosional remnant of a northeasterly migrating delta channel that has cut into the underlying section (Collett and others, 1988). East of the Prudhoe Bay area, the EOCU has eroded a portion of the nonmarine/nearshore marine section removing the $\mathrm{C} 16$ marker (figs. 9 and 10). From the Kuparuk River field area to the west and southwest, however, the EOCU is not present (Collett and others, 1988).

Little is known about the rock units overlying the $\mathrm{C} 17$ marker. These rock units consist of sediments deposited in a delta-platform environment and are generally of uniform composition both laterally and vertically (Collett and others, 1988). As seen in the cross sections presented with this report (figs. 2-10), the thicknesses of these rock units vary considerably depending on location, but there is a general stratigraphic thickening from the southwest to the northeast. Collett and others (1988) suggested that this thickening may represent the northeastward progradation of the deltaic depocenter. Thinning is also observed for some of these shallow rock units, but whether this thinning is representative of a regional depositional hiatus or unconformity cannot be determined with the well $\log$ database presently available.

\section{Gas Hydrate Stability Conditions of the Alaska North Slope}

As previously discussed, the three primary factors that control the distribution of the gas hydrate stability zone are geothermal gradient, composition of the gas contained within the gas hydrate clathrate structure, and pore-pressure gradient. In order to calculate the regional geothermal gradients needed for determining the distribution of the hydrate stability zone, accurate subsurface temperature data are required. Although several methods for obtaining the necessary subsurface temperatures exist, such as theoretical derivation and calculation from bottom-hole temperature measurements acquired during well logging, the best and most accurate method for determining the local and regional geothermal gradients is by obtaining high-resolution temperature surveys in wells that have been left undisturbed long enough to allow thermal equilibration of the wellbore (Collett and others, 1988).

Since 1958, high-resolution temperature surveys have been acquired in 46 wells on the North Slope of Alaska that were considered to be in thermal equilibrium (Lachenbruch and others, 1987; Lee and others, 2008). Although the geothermal gradients needed for determining the gas hydrate stability distribution can be derived directly from these temperature measurements, the coverage of wells with these temperature surveys is relatively sparse. In order to augment these measurements, Collett and others (1988) developed a method for evaluating local geothermal gradients using well log picks for the base of the ice-bearing permafrost. Collett and others (1988) derived regional temperature constants from the high-resolution, equilibrated geothermal gradient data from Lachenbruch and others (1987) and then picked the base of the ice-bearing permafrost for an additional 102 wells. For each of the wells, Collett and others (1988) projected a geothermal gradient from the equilibrium surface temperatures to the depth and temperature at the base of the ice-bearing permafrost. By computing a ratio of the geothermal gradient above and below the base of ice-bearing permafrost, the projected geothermal gradients within the ice-bearing permafrost were related to the projected geothermal gradients below the base of ice-bearing permafrost. These projected gradients were then combined with the gradients measured from the highresolution temperature surveys, which were, in turn, used to extrapolate the geothermal gradient to areas with little or no temperature data. The geothermal gradients measured from the high-resolution temperature surveys and those determined using the projection method of Collett and others (1988) were similar over most of the Alaska North Slope. The gradients calculated using both methods range from approximately $1.5^{\circ} \mathrm{C} / 100 \mathrm{~m}$ in the Prudhoe Bay area to approximately $5.0^{\circ} \mathrm{C} / 100 \mathrm{~m}$ in the NPRA (Collett and others, 2011). Until recently, most gas hydrate studies of the Alaska North Slope assumed that the gas was 100-percent methane (Collett, 1995). Analysis of mud-log gas-chromatograph data from 320 industry-drilled wells indicated that the shallow strata $(0-1,500 \mathrm{~m})$ of the North Slope contain predominantly methane, but the analysis of gas exsolved from the hydrates in the Northwest Eileen State-2 well showed a more complex gas chemistry (Collett and others, 1988). In several of the Northwest Eileen State-2 samples, nitrogen, which inhibits hydrate development, was detected in addition to methane. However, repeat analysis on those same samples yielded a 100-percent pure methane composition (Collett and others, 1988). In later studies, Collett (1993) and Lorenson and others (2011) analyzed the gas exsolved from cores recovered in the gas 
hydrate-bearing sedimentary section from wells in both the Prudhoe Bay and Milne Point areas, confirming methane to be the dominant gas. Therefore, although some uncertainty may exist surrounding the Northwest Eileen State-2 samples, utilizing a pure methane gas hydrate composition seems reasonable for at least the Prudhoe Bay and Milne Point areas.

Typically, most gas hydrate stability studies assume a hydrostatic pore-pressure gradient of $9.795 \mathrm{kPa} / \mathrm{m}$ $(0.433 \mathrm{psi} / \mathrm{ft})$. Subsurface pore-pressure gradients derived from shut-in well pressures recorded during shallow (depths of 400 to $2,000 \mathrm{~m}$ ) drill-stem tests in 17 North Slope wells range from 9.3 to $11.2 \mathrm{kPa} / \mathrm{m}$ (0.41 to $0.50 \mathrm{psi} / \mathrm{ft})$, with an average of $9.7 \mathrm{kPa} / \mathrm{m}(0.43 \mathrm{psi} / \mathrm{ft})$ (Collett, 1993). Moreover, no porepressure discontinuities were observed in analyses of compaction profiles from 22 wells (Collett, 1993). Therefore, the use of a hydrostatic pore-pressure gradient appears to be a valid assumption for the North Slope of Alaska.

In addition to the temperature gradient, gas chemistry, and pore-pressure gradient, other fluid and rock properties can also affect the formation of gas hydrates. Salt, when added to a gas hydrate system, lowers the temperature at which gas hydrates form. Through the use of well logs and water-sample analysis, Collett (1993) observed that pore-water salinities within the sands both above and below the ice-bearing permafrost were low for the Alaska North Slope, ranging from $<1.0$ part per thousand (ppt) to as high as 19 ppt. This finding was later confirmed in 2008 from analysis of core-derived pore waters from the BPXA-DOE-USGS Mount Elbert Gas Hydrate Stratigraphic Test Well, where the average background salinity concentration was approximately $5 \mathrm{ppt}$ (Collett and others, 2011).

Using the properties listed above, Collett and others (2008) calculated the extent of the GHSZ for the Alaska North Slope (fig. 18). The gas hydrate stability maps (figs. $18 \mathrm{~A}$ and $18 B$ ), along with the depths for the top and base of the GHSZ calculated directly from the high-resolution temperature surveys, were used to determine the tops and bases of the hydrate stability zone for the wells used in this report (table 1, figs. 2-10).

\section{Gas Hydrates of the Alaska North Slope}

Until the drilling of the BPXA-DOE-USGS Mount Elbert Gas Hydrate Stratigraphic Test well in 2008, the only direct confirmation of gas hydrate existence on the Alaska North Slope was from the ARCO-Exxon Northwest Eileen State-2 well (well no. 53, fig. 5). Log data show that this well encountered three gas hydrate-bearing stratigraphic units (fig. 19). In an effort to reduce the thawing of the permafrost and decomposition of any in situ gas hydrate that existed, the Northwest Eileen State-2 well was drilled with chilled drilling mud, and a pressure core system was utilized to recover core samples at near in situ conditions to minimize gas hydrate dissociation related to the coring process. Through pressure testing of the recovered core, Hunt (1979) further confirmed the presence of gas hydrate in the well.

Using the results from the Northwest Eileen State-2 well for comparison, Collett (1993) examined 445 North Slope wells for evidence of gas hydrate presence. Most of these wells were located in the Prudhoe Bay-Kuparuk River area, but Collett (1993) also examined all of the wells in NPRA and most of the exploratory wells located to the south and east of the Prudhoe Bay area. Of those 445 wells, 50 showed evidence of gas hydrates on the well logs (see table 1 of Collett, 1993). All 50 of these wells were located in the Prudhoe BayKuparuk River area.

Since the Collett (1993) report, Collett and others (2008), Lee and others (2008), and Inks and others (2009) examined an additional 200 exploratory and development wells on the Alaska North Slope for the presence of gas hydrates and determined that two large accumulations exist on the Alaska North Slope. These two accumulations, named the Eileen and Tarn gas hydrate accumulations, are located in the Prudhoe Bay-Kuparuk River-Milne Point and Tarn-Meltwater areas, respectively (fig. 11) (Collett and others, 2011).

As discussed by Collett (1993), the Eileen gas hydrate accumulation consists of six laterally continuous gas hydratebearing sandstone units, designated by letters $\mathrm{A}$ through $\mathrm{F}$ in ascending order (fig. 20), that individually range in thickness from 3 to $30 \mathrm{~m}$. The lateral boundaries of these units were determined by Collett (1993) from well logs, but because the well control is widely spaced in many areas, the mapped position of the gas hydrate unit boundaries is open to interpretation and further refinement (Collett, 1993). More recent gas hydrate prospecting completed by Inks and others (2009) using 3-D seismic data has helped to further refine the lateral extent of the well log-inferred gas hydrate accumulations. The areal extent of the individual gas hydrate units range from 3 to $404 \mathrm{~km}^{2}$, representing a total area of approximately $1,643 \mathrm{~km}^{2}$ (Collett and others, 2011). The total volume of gas contained within the Eileen accumulation has been estimated by Collett (1993) to range from 1.0 to 1.2 trillion cubic meters (35.342.4 trillion cubic feet).

Collett (1993) concluded that the Eileen gas hydrate accumulation was in rocks of the Mikkelsen Tongue of the Canning Formation. However, more recent analysis of the core from the Mount Elbert Stratigraphic Test well indicates that the gas hydrate-bearing units of the Eileen accumulation consist mainly of fine- to very fine grained sands and coarse silts with minor interbedding of coarse sands, conglomerates, and shales that were deposited in nearshore marine and nonmarine environments (Rose and others, 2011). This description is more characteristic of Sagavanirktok Formation, to which the Eileen gas hydrate unit is now assigned (Molenaar and others, 1987; Bird, 1998; Rose and others, 2011). The Sagavanirktok is considered to be age-equivalent to the Eocene marine shales and minor sands of the Mikkelsen Tongue of the Canning Formation located farther to the east (fig. 16) (Collett and others, 2011). 

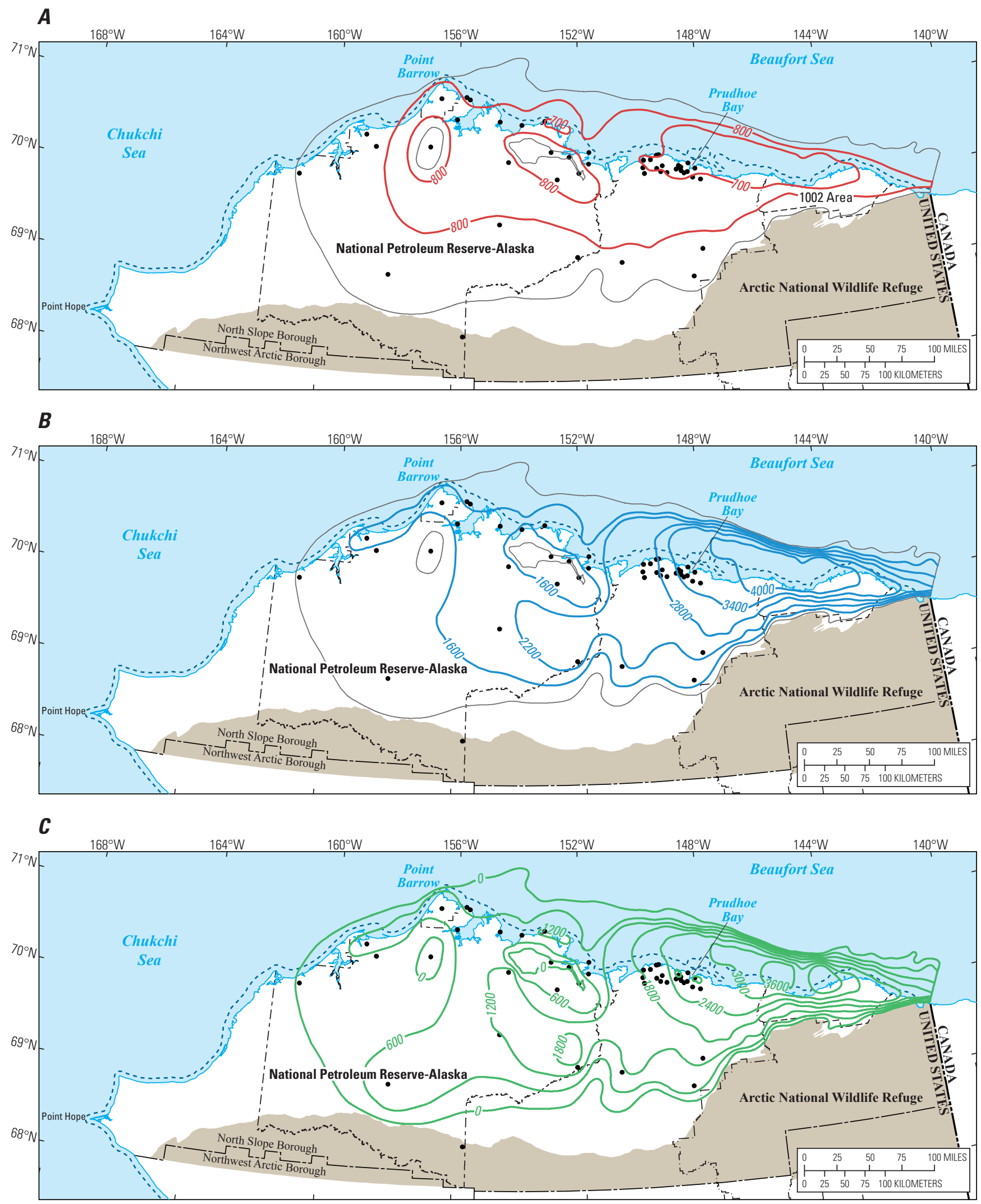

Figure 18. Maps of the Alaska North Slope gas hydrate stability zone (modified from Collett and others, 2008; Collett and others, 2011). A. Depth to the top of the hydrate stability zone. B. Depth to the base of the hydrate stability zone. $C$. Thickness of the hydrate stability zone. Contours are given in feet. 
Base from U.S. Geological Survey digital data

Albers Conical Equal area projection

Standard parallels $55^{\circ} \mathrm{N}$ and $65^{\circ} \mathrm{N}$

Central meridian $154^{\circ} \mathrm{W}$, latitude of origin $50^{\circ} \mathrm{N}$

North American Datum of 1927 (NAD 27)

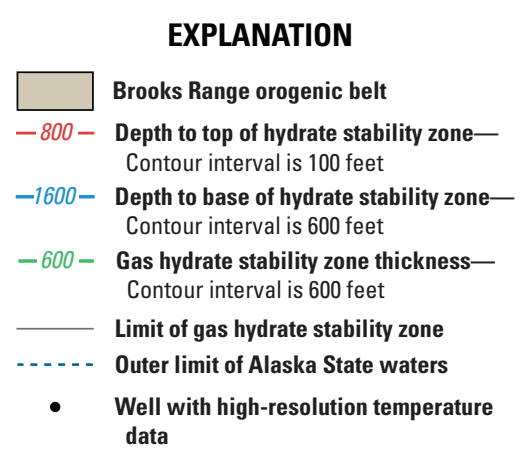

data

Figure 18 (above and previous page). Maps of the Alaska North Slope gas hydrate stability zone (modified from Collett and others, 2008; Collett and others, 2011). A. Depth to the top of the hydrate stability zone. $B$. Depth to the base of the hydrate stability zone. $C$. Thickness of the hydrate stability zone. Contours are given in feet.-Continued

The Tarn gas hydrate accumulation was first identified in 1992 with the drilling of the Cirque-1 well located just west of the Kuparuk River field (fig. 11). As detailed by the Alaska Oil and Gas Conservation Commission (1992), this well encountered a shallow gas zone that subsequently caused the well to blow out. Collett and Dallimore (2002) determined that, in addition to the shallow gas zone, the Cirque-1 well also encountered a thick gas hydrate-bearing zone likely contributed to the gas flow that caused the Cirque-1 blowout. Later in 1992, drilling of the Cirque-2 well confirmed the presence of gas hydrates near the base of the permafrost in the depth range of 250-350 $\mathrm{m}$ (Collett and Dallimore, 2002). As shown by Collett (1993), Collett and others (2011), and in the well correlation sections of this report, the gas hydrate accumulation encountered in the Cirque- 1 and Cirque- 2 wells can be correlated to the gas hydrate present in other wells located west of the Kuparuk River area. Now known as the Tarn hydrate accumulation, it extends from the Meltwater field area northward to the vicinity of the Till-1 well and is located west of the Kuparuk River area and to the east of NPRA (fig. 11).

From the well correlation sections included with this report, the Tarn gas hydrate-bearing stratigraphic unit appears to be in the shallow marine deposits of the Schrader Bluff Formation or, following the nomenclature of Werner (1987), the updip equivalent of the West Sak sands (figs. 1, 2, 4, 6, and 7). Analyses of additional wells located to the west of the Kuparuk River field indicate that the Tarn gas hydrate may, in fact, be larger than the Eileen accumulation (Collett and others, 2011). However, in contrast to the latter, which straddles the base of permafrost, the Tarn accumulation lies mostly within the permafrost zone, making the analysis of this section with well logs difficult.

Although the Eileen and Tarn are two separate gas hydrate accumulations, they share similar properties, in that both (1) form pore-filling substances that are mostly found in coarse-grained sedimentary rock, (2) exist completely within the gas hydrate stability zone of the Alaska North Slope as calculated by Collett and others (2008), and (3) contain methane as the principal hydrocarbon gas (Collett, 1993). Furthermore, methane-carbon isotope analyses determined that the methane is both microbial and thermogenic in origin (Collett and others, 2011). As was discussed previously, the thermogenic portion of the methane was likely derived from deeper sources and then migrated upward into its current stratigraphic position.

Throughout the Prudhoe Bay area, a series of northwesttrending high-angle normal faults cut the Sagavanirktok Formation (Werner, 1987). Similarly, the older rocks of this area are cut by a series of northwest-trending faults that are likely genetically linked to those within the Sagavanirktok Formation (Collett and others, 2011). These fault systems could have served as conduits for oil and gas migration from the Kuparuk River and Prudhoe Bay accumulations to the overlying formations such as the Sagavanirktok. The oil contained within the Sagavanirktok Formation has similar geochemical properties to the oil from the underlying Prudhoe Bay accumulation, leading Carman and Hardwick (1983) and Masterson and others (2001) to suggest that the Sagavanirktok oil, and presumably the gas, originated and migrated upward from the Prudhoe Bay Sadlerochit reservoir (fig. 16) as a consequence of the regional tilting of the Barrow arch (fig. 15) as the result of tectonic loading, probably during the Eocene (Bird and Houseknecht, 2011). Consequently, Collett (1993) and Collett and others (2011) concluded that the thermogenic gas contained within the Eileen and Tarn gas hydrates was also likely sourced from the Sadlerochit Group in the Prudhoe Bay accumulation. Collett (1993) and Collett and others (2011) postulated that the Eileen and other fault zones served as conduits for the thermogenic gas of the deeper Sadlerochit Group and as this gas migrated upward and encountered the porous and permeable northeast-dipping Sagavanirktok reservoir, some of the gas migrated updip along the permeable beds of the Sagavanirktok, accumulated in structural and stratigraphic traps, and intermingled with in situ biogenic methane (fig. 21). As temperatures dropped at the end of the Pliocene, the permafrost deepened and converted this trapped gas into the Tarn and Eileen gas hydrates. 

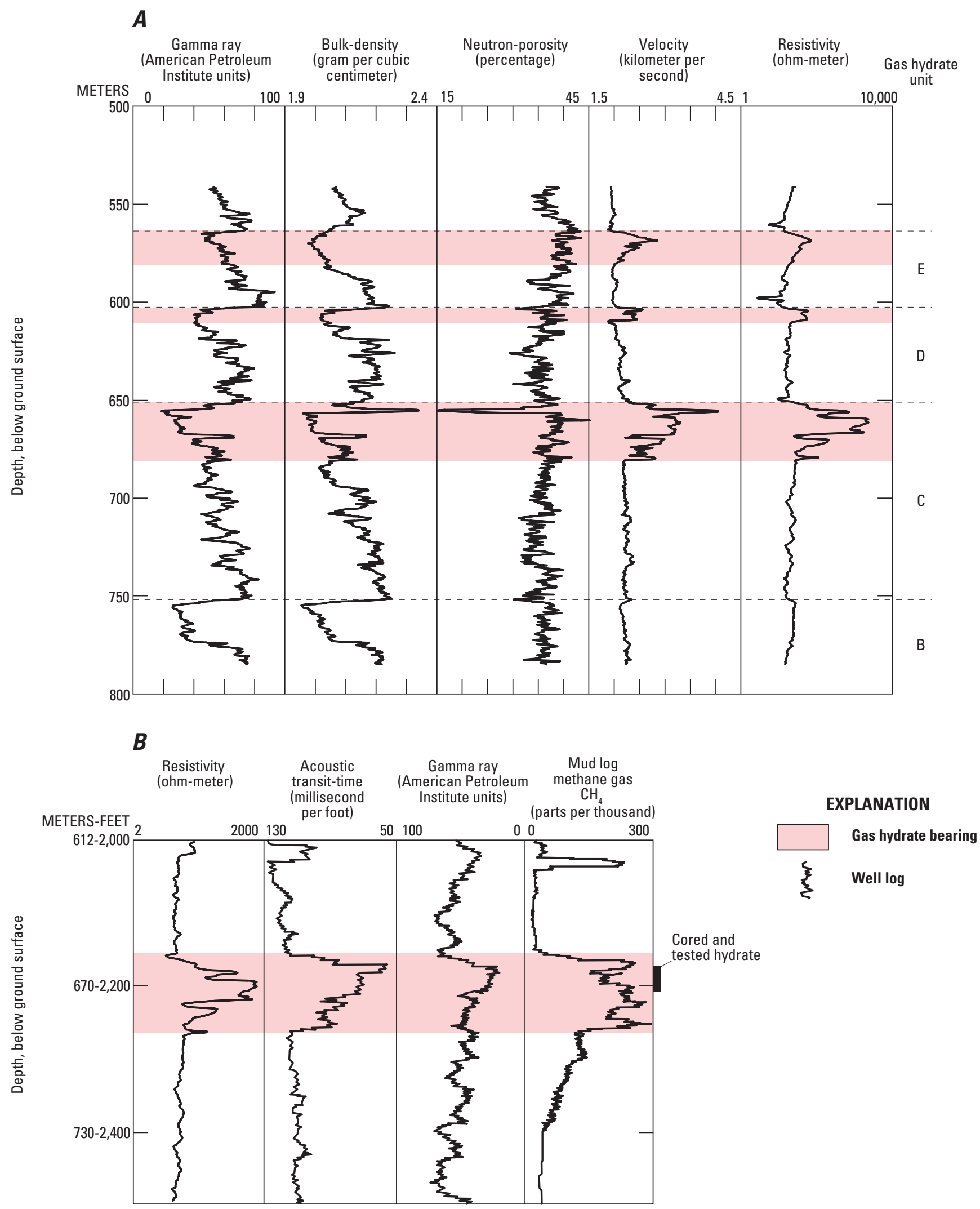

Figure 19. A. Well logs from Northwest Eileen State-2 well highlighting the gas hydrate-bearing units B, C, D, and E (Collett, 1993). The well logs shown include the natural gamma ray, bulk-density, neutron porosity, acoustic velocity, and electrical resistivity. $B$. Insert of well logs from the cored (664-687 meters) gas hydrate interval (unit C) in the Northwest Eileen State-2 well. Data shown include well logs and the methane $\left(\mathrm{CH}_{4}\right)$ mud log curve. 
SOUTHWEST

NORTHEAST

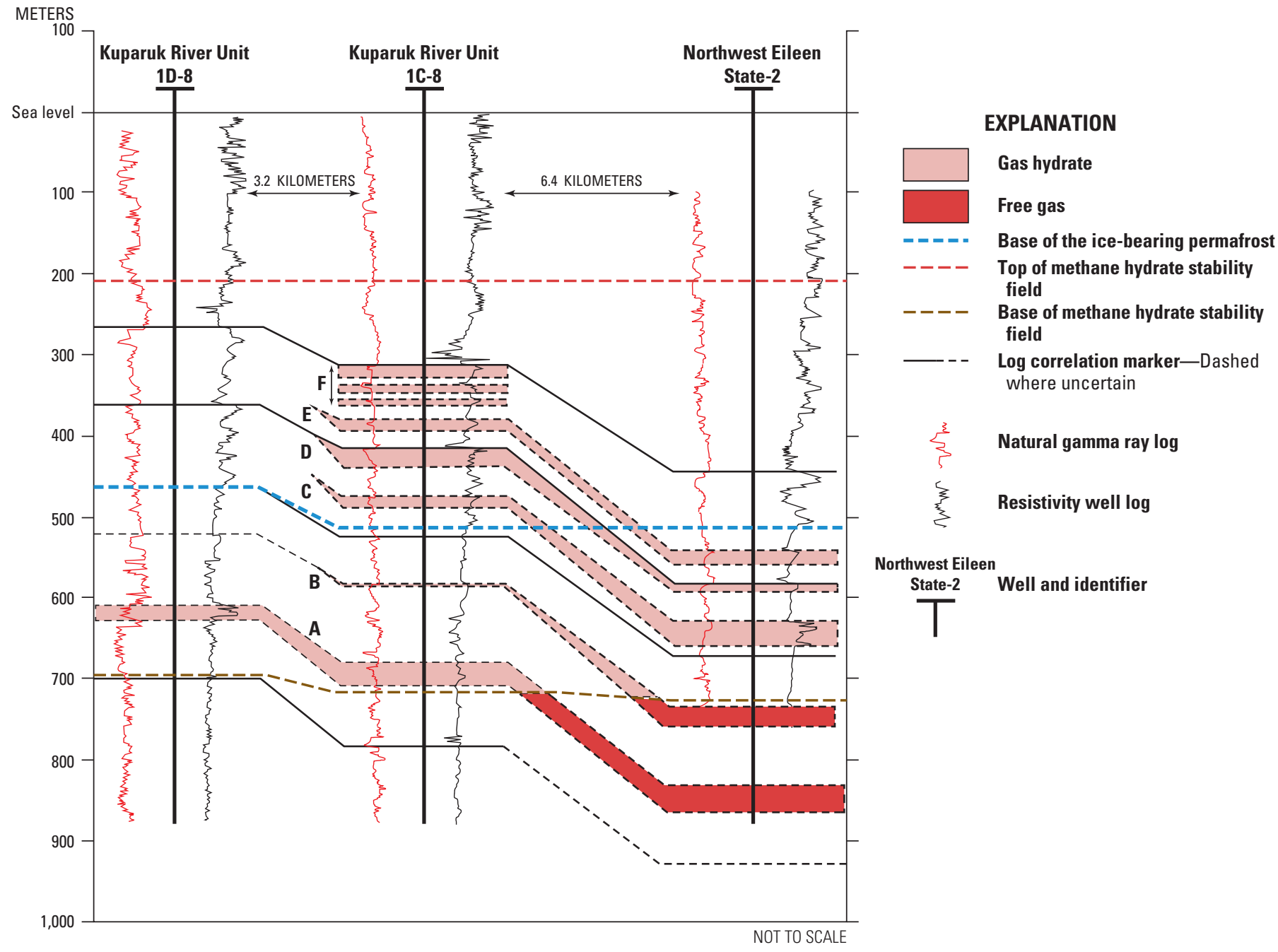

Figure 20. Cross section showing the gas hydrate-bearing units $A$ through $F$ and their relations to the top and base of the gas hydrate stability zone (red and brown dashed lines) and the base of the ice-bearing permafrost (blue dashed line) (modified from Collett, 1993). The natural gamma ray and resistivity well logs are displayed for each well. The solid lines are log correlation markers to demonstrate the regional stratigraphic framework. The correlation markers are dashed where uncertain.

Work completed by both Masterson and others (2001) and Lorenson and others (2011) supports Collett's (1993) interpretation of gas migration. Through geochemical analysis of the Prudhoe Bay, Kuparuk River, and West Sak hydrocarbons, Masterson and others (2001) concluded that gas and condensate of the Kuparuk River field leaked vertically and migrated up into the West Sak reservoir via the Eileen fault system (fig. 21). Drawing on the work of Masterson and others (2001), Lorenson and others (2011) also used geochemical analysis of the gases contained within the Eileen gas hydrates and concluded that the thermogenic portion of the gas encountered in the Mount Elbert well most likely migrated upward from deeper strata and followed the preferential migration pathways provided by the Eileen and surrounding fault systems. During the period of depressed temperatures at the end of the Pliocene, this migrating thermogenic gas then crystallized and formed the present-day Eileen and Tarn gas hydrate accumulations.

\section{Well Log Detection of Gas Hydrates}

Throughout the years, naturally occurring gas hydrate accumulations commonly have been detected using well logs; Bily and Dick (1974) were among the first to discover the usefulness of well logs for that purpose. In their work on the Mackenzie Delta, Bily and Dick (1974) discovered that there was a marked increase in the amount of gas contained within the drilling mud when gas hydrate accumulations were penetrated, and these same gas hydrate accumulations corresponded to relatively high resistivities on the dual induction 
$\log$ and increased acoustic velocities on the acoustic sonic $\log$. Since this time, Collett (1993) and many others have also confirmed these well log responses to the presence of gas hydrates.

As discussed by Collett (1993), Collett (2002), and Collett and others (2011), gas hydrates can typically be detected using two types of well logs, the electrical resistivity and acoustic sonic logs. In general, a gas hydrate-bearing sedimentary unit is characterized by high electrical resistivities and high acoustic velocities (fig. 19). However, because gas hydrates consist of approximately 85-percent water on a molecular basis and, hence, have similar properties to ice, resistivity and acoustic sonic logs behave similarly in reservoirs containing either ice or gas hydrates. Typically, the only way to definitively differentiate gas hydrate from ice is through the use of mud logs. As drilling penetrates the gas hydrate-bearing sedimentary section, heat produced by the drilling activity can cause the gas hydrate to dissociate and release gas. This dissociated gas appears as gas "shows" on the mud $\log$ (fig. 19). Conversely, no gas "shows" on the mud log suggests that the sedimentary section contains only ice.

To assist in determining the presence of gas hydrates in the study wells, the top and base of the gas hydrate stability zone are plotted on each of the well correlation sections (figs. $2-10)$. The boundaries of the gas hydrate stability zone as determined using the projection method of Collett and others (1988) are indicated by red lines, with the extent of the gas hydrate stability zone denoted by pink shading. For wells that have high-resolution temperature surveys available, the depth at which $0{ }^{\circ} \mathrm{C}$ occurs is indicated with a cyan-colored line, and the top and base of the GHSZ calculated from the temperature survey are shown as light-green lines. Because of the close relation between gas hydrates and the occurrence of permafrost, picks for the base of the ice-bearing permafrost are also included and are indicated with a blue line. Following typical convention, any picks that were uncertain or were projected from surrounding wells are displayed with dashed lines.

Possible gas hydrate unit picks were first identified using resistivity and acoustic sonic logs. Once identified, mud logs, if available, were used to definitively determine that the potential gas hydrate picks were actually gas hydrate, as opposed to permafrost. If a mud log was not available, the possible gas hydrate pick was flagged as a possible but unconfirmed gas hydrate and is indicated by an asterisk on the well log correlation sections. All of the hydrate accumulations are shaded in yellow and are labeled with the appropriate hydrate unit (that is, units $\mathrm{A}-\mathrm{F}$ ).

\section{Assessments of the Alaska North Slope Gas Hydrates}

In 1995, the U.S. Geological Survey completed an assessment of the undiscovered conventional and unconventional resources of crude oil and natural gas in the United States
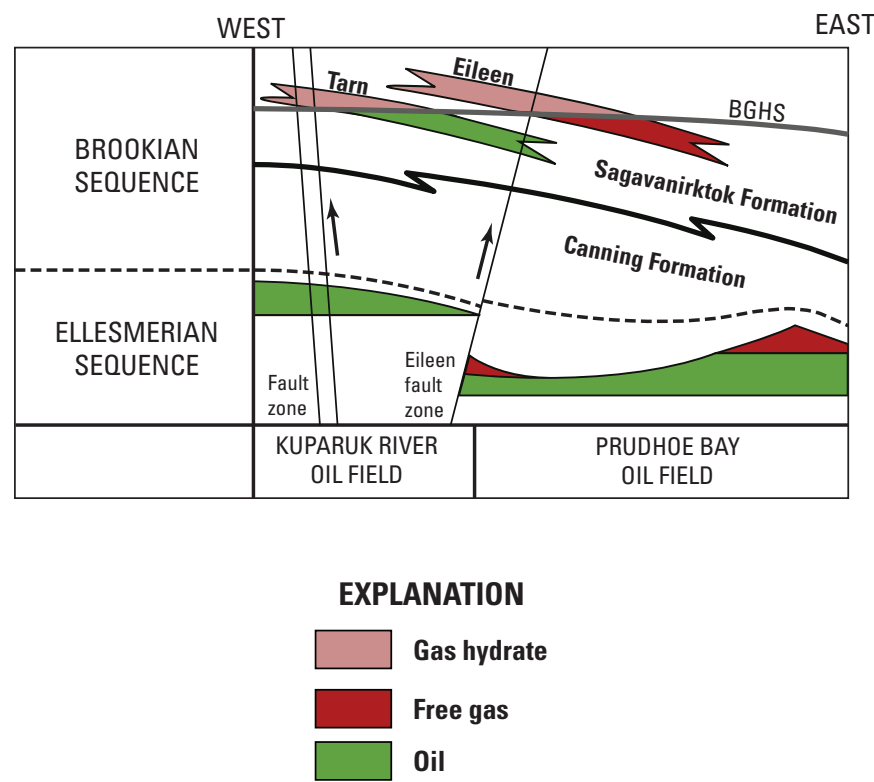

Figure 21. Schematic cross section through the Prudhoe Bay and Kuparuk River oil fields illustrating possible gas migration pathways (fault zones) and their spatial relations to the Tarn and Eileen gas hydrate accumulations (Collett and others, 2011). BGHS $=$ base of gas hydrate stability zone.

as part of the National Assessment of United States Oil and Gas Resources project. As part of the assessment program, a systematic appraisal of the in-place natural gas hydrate resources of the U.S. onshore and offshore was completed for the first time, resulting in an estimate of 16.7 trillion cubic meters (590 trillion cubic feet) of gas in the ANS gas hydrate deposits (Collett, 1995). Because the assessment only dealt with in-place estimates, it did not deal with how much natural gas could be produced from the gas hydrates. Building on the 1995 assessment, the USGS completed another assessment of the gas hydrates in 2008. This time, however, the USGS assessed the undiscovered technically recoverable gas hydrate resources of the Alaska North Slope (Collett and others, 2008). The area of the assessment extended from the NPRA eastward to the Arctic National Wildlife Refuge and from the Brooks Range northward to the State-Federal offshore boundary, an area of approximately $114,765 \mathrm{~km}^{2}$ of Federal, State, and Native lands (Collett and others, 2008).

What made the 2008 assessment different from a more typical USGS assessment is that, in this case, an unconventional resource in discrete hydrocarbon traps and structures was assessed without any known history as a producible resource. This was accomplished by defining a total petroleum system for the North Slope gas hydrates that was then used following conventional petroleum assessment methodologies (Collett and others, 2008). The USGS utilized industryacquired 3-D seismic data along with conventional well log and other geologic methodologies and numerical modeling to conduct the assessment. Through their work, Collett and 
others (2008) determined that the gas hydrates of the North Slope occupy discrete volumes of fault-bounded rock as a pore-filling substance. Because no long-term production of gas hydrates has yet been tested, the USGS utilized extensive numerical production modeling to estimate the amount of gas that could be produced from the North Slope gas hydrates (Anderson and others, 2008). Results of this modeling effort suggest that gas hydrate-bearing reservoirs can produce gas using conventional technology.

Applying the methodology described above, the USGS determined that the total undiscovered, technically recoverable natural gas existing within the Alaska North Slope gas hydrates ranges from 0.71 to 4.47 trillion cubic meters (approximately 25.2 to 157.8 trillion cubic feet) representing probabilities of occurrence of 95 and 5 percent, respectively (Collett and others, 2008). The technically recoverable resource was estimated at a mean of 2.42 trillion cubic meters (approximately 85.4 trillion cubic feet) (Collett and others, 2008). Unlike previous studies of the Alaska North Slope gas hydrates, Collett and others (2008) inferred for the first time that gas hydrates formed not only the Eileen and Tarn accumulations of the Sagavanirktok Formation but also in other shallow formations. Based on the revised calculations of the GHSZ, Collett and others (2008) speculated that gas hydrates could be present in Cretaceous and Tertiary sedimentary rocks of the North Slope. Consequently, Collett and others (2008) assigned gas hydrate resources to the Nanushuk, Tuluvak, Schrader Bluff, and Prince Creek Formations. However, due to the lack of gas hydrate well penetrations on the North Slope, significant uncertainty remains regarding the presence of gas hydrate outside the Prudhoe Bay-Milne Point-Kuparuk River area. Consequently, significant uncertainty exists in the estimates reported by Collett and others (2008) reflected by the wide range of the volumes reported in the assessment. For a more detailed review of the 2008 USGS assessment, please refer to Collett and others (2008) and Collett and others (2011).

\section{Summary}

Gas hydrate research has had a long history in northern Alaska, and the USGS has played a significant role in that research. Using information generated from the two gas hydrate stratigraphic test wells and a wealth of other geological and geophysical information, the USGS has assessed the mean technically recoverable resource associated with hydrates in northern Alaska to be 2.42 trillion cubic meters (85.4 trillion cubic feet). The nine well log correlation sections presented with this report highlight the stratigraphic framework and the extent of the gas hydrate stability zone on the Alaska North Slope. Of the 122 wells examined for this study, downhole logs from 19 of the wells confirm the presence of gas hydrates. Although knowledge about the gas hydrates of the Alaska North Slope has grown significantly through recent years, much is still unknown regarding their formation. Due to the extensive research completed there, the Alaska North Slope will likely continue to play a significant role for future gas hydrate research.

\section{References Cited}

Alaska Oil and Gas Conservation Commission, 1992, Summary of the Cirque-1 blowout of February 12, 1992: Public Record Letter from D.J. Ruckel, ARCO Alaska, to D. Johnston, State of Alaska Oil and Gas Conservation Commissioner, Anchorage, Alaska, $32 \mathrm{p}$.

Anderson, B.J., Wilder, J.W., Kurihara, Masanori, White, M.D., Moridis, G.J., Wilson, S.J., Pooladi-Darvish, Mehran, Masuda, Yoshihiro, Collett, T.S., Hunter, R.B., Narita, Hideo, Rose, K.K., and Boswell, Ray, 2008, Analysis of modular dynamic formation test results from the Mount Elbert 01 stratigraphic test well, Milne Point Unit, North Slope, Alaska: Proceedings of the 6th International Conference on Gas Hydrates (ICGH 2008), July 6-10, 2008, Vancouver, British Columbia, Canada, 10 p.

Bard, H.B., and Fairbanks, R.G., 1990, U-Th ages obtained by mass spectrometry in corals from Barbados, sea level during the past 130,000 years: Nature, v. 346, p. 456-458.

Bily, Charles, and Dick, J.W.L., 1974, Naturally occurring gas hydrates in the Mackenzie Delta, N.W.T.: Bulletin of Canadian Petroleum Geology, v. 22, no. 3, p. 340-352.

Bird, K.J., 1998, Geographic and geologic setting, in U.S. Geological Survey Assessment Team, The oil and gas resource potential of the Arctic National Wildlife Refuge 1002 area, Alaska: U.S. Geological Survey Open-File Report 98-34, p. GG1-GG51.

Bird, K.J., 2001, Alaska: A twenty-first-century petroleum province, in Downey, M.W., Threet, J.C., Morgan, W.A., eds., Petroleum provinces of the twenty-first century: American Association of Petroleum Geologists Memoir 74, p. 137-165.

Bird, K.J., and Houseknecht, D.W., 2011, Geology and petroleum potential of the Arctic Alaska petroleum province, in Spencer, A.M., Embry, A.F., Gautier, D.L., Stoupakova, A.V., and Sørensen, Kai, eds., Arctic petroleum geology: Geological Society, London, Memoir 35, p. 485-499.

Boswell, Ray, Rose, K.K., Collett, T.S., Lee, M.W., Winters, W.J., Lewis, K.A., and Agena, W.F., 2011, Geologic controls on gas hydrate occurrences in the Mount Elbert prospect, Alaska North Slope: Journal of Marine and Petroleum Geology, v. 28, p. 589-607. 
Brown, Jerry, Ferrians, O.J., Jr., Heginbottom, J.A., and Melnikov, E.S., 2002, Circum-arctic map of permafrost and ground-ice conditions, version 2: Boulder, Colo., National Snow and Ice Data Center.

Carman, G.J., and Hardwick, Peter, 1983, Geology and regional setting of the Kuparuk oil field, Alaska: American Association of Petroleum Geologists Bulletin, v. 67, no. 6, p. 1014-1031.

Collett, T.S., 1993, Natural gas hydrates of the Prudhoe Bay and Kuparuk River area, North Slope, Alaska: American Association of Petroleum Geologists Bulletin, v. 77, no. 5, p. $793-812$.

Collett, T.S., 1994, Permafrost-associated gas hydrate accumulations: Annals of the New York Academy of Sciences, v. 715 , p. 247-269.

Collett, T.S., 1995, Gas hydrate resources of the United States, in Gautier, D.L., Dolton, G.L., Takahashi, K.I., and Varnes, K.L., eds., 1995 national assessment of United States oil and gas resources: U.S. Geological Survey Digital Data Series, v. 30, CD-ROM, 48 p.

Collett, T.S., 2002, Energy resource potential of natural gas hydrates: American Association of Petroleum Geologists Bulletin, v. 86, no. 11, p. 1971-1992.

Collett, T.S., Agena, W.F., Lee, M.W., Zyrianova, M.V., Bird, K.J., Charpentier, T.C., Houseknect, D.W., Klett, T.R., Pollastro, R.M., and Schenk, C.J., 2008, Assessment of gas hydrate resources on the North Slope, Alaska, 2008:

U.S. Geological Survey Fact Sheet 2008-3070, 4 p.

Collett, T.S., Bird, K.J., Kvenvolden, K.A., and Magoon, L.B., 1988, Geologic interrelations relative to gas hydrates within the North Slope of Alaska: U.S. Geological Survey OpenFile Report 88-389, 150 p.

Collett, T.S., and Dallimore, S.R., 2002, Detailed analysis of gas hydrate induced drilling and production hazards: Proceedings of the Fourth International Conference on Gas Hydrates, Yokohama, Japan, May 19-23, p. 47-52.

Collett, T.S., Johnson, A.H., Knapp, C.C., and Boswell, Ray, 2009, Natural gas hydrates-A review, in Collett, T.S., Johnson, A.H., Knapp, C.C., Boswell, Ray, eds., Natural gas hydrates-Energy resource potential and associated geologic hazards: American Association of Petroleum Geologists Memoir, v. 89, p. 146-219.

Collett, T.S., Lee, M.W., Agena, W.F., Miller, J.J., Lewis, K.A., Zyrianova, M.V., Boswell, Ray, and Inks, T.L., 2011, Permafrost-associated natural gas hydrate occurrences on the Alaska North Slope: Journal of Marine and Petroleum Geology, v. 28, p. 279-294.
Dallimore, S.R., and Collett, T.S., eds., 2005, Scientific results from the Mallik 2002 Gas Hydrate Production Research Well Program, Mackenzie Delta, Northwest Territories, Canada: Geological Survey of Canada Bulletin 585, two CD-ROM set.

Decker, P.L., 2007, Brookian sequence stratigraphic correlations, Umiat field to Milne Point field, west-central North Slope Alaska: Alaska Department of Natural Resources Division of Geological and Geophysical Surveys Preliminary Interpretive Report 2007-2, 19 p.

Ferrians, O.J., Jr., 1994, Permafrost in Alaska, in Plafker, George, and Berg, H.C., eds., The geology of Alaska: Boulder, Colo., Geological Society of America, The Geology of North America, v. G-1, p. 845-854.

Gradstein, F.M., Ogg, J.G., and Smith, A.G., 2004, A geologic time scale 2004: Cambridge University Press, 589 p.

Holder, G.D., Malone, R.D., and Lawson, W.F., 1987, Effects of gas composition and geothermal properties on the thickness and depth of natural-gas-hydrate zone: Journal of Petroleum Technology, September, p. 1147-1152.

Houseknecht, D.W., and Bird, K.J., 2006, Oil and gas resources of Arctic Alaska Petroleum Province: U.S. Geological Survey Professional Paper 1732-A, 11 p.

Houseknecht, D.W., Bird, K.J., and Schenk, C.J., 2009, Seismic analysis of clinoform depositional sequences and shelf-margin trajectories in Albian strata, Alaska North Slope: Basin Research, v. 21, p. 644-654.

Hunt, J.M., 1979, Petroleum geology and geochemistry: San Francisco, Calif., Freeman, 716 p.

Hunter, R.B., Collett, T.S., Boswell, Ray, Anderson, B.J., Digert, S.A., Pospisil, Gordon, Baker, Richard, and Weeks, Micaela, 2011, Mount Elbert Gas Hydrate Stratigraphic Test well, Alaska North Slope: Overview of scientific and technical program: Journal of Marine and Petroleum Geology, v. 28 , no. 2 , p. $295-310$.

Hyndman, R.D., and Davis, E.E., 1992, A mechanism for the formation of methane hydrate and seafloor bottomsimulating reflectors by vertical fluid expulsion: Journal of Geophysical Research, v. 97, p. 7025-7041.

Inks, T.L., Lee, M.W., Agena, W.F., Taylor, D.J., Collett, T.S., Hunter, R.B., and Zyrianova, M.V., 2009, Seismic prospecting for gas hydrate and associated free-gas prospects in the Milne Point area of northern Alaska, in Collett, T.S., Johnson, A.H., Knapp, C.C., and Boswell, Ray, eds., Natural gas hydrates-Energy resource potential and associated geologic hazards: American Association of Petroleum Geologists Memoir, v. 89, 145 p. 
Jamison, H.C., Brockett, L.D., and McIntosh, R.A., 1980, Prudhoe Bay-A 10-year perspective, in Halbouty, M.T., ed., Giant oil and gas fields of the decade 1968-1978: American Association of Petroleum Geologists Memoir 30, p. 289-314.

Judge, A.S., Smith, S.L., and Majorowicz, J.A., 1994, The current distribution and thermal stability of natural gas hydrates in the Canadian Polar Regions: Proceedings of the Fourth International Offshore and Polar Engineering Conference, Osaka, Japan, p. 307-313.

Kvenvolden, K.A., 1993a, A primer in gas hydrates, in Howell, D.G., ed., The future of energy gases: U.S. Geological Survey Professional Paper 1570, p. 279-292.

Kvenvolden, K.A., 1993b, Gas hydrates as a potential energy resource-A review of their methane content, in Howell, D.G., ed., The future of energy gases: U.S. Geological Survey Professional Paper 1570, p. 555-561.

Lachenbruch, A.H., Sass, J.H., Lawver, L.A., Brewer, M.C., Marshall, B.V., Munroe, R.J., Kennelly, J.P., Jr., Galanis, S.P., Jr., and Moses, T.H., Jr., 1987, Temperature and depth of permafrost on the Alaskan North Slope, in Tailleur, I.L., and Weimer, Paul, eds., Alaskan North Slope geology: Pacific Section, Society of Economic Paleontologists and Mineralogists and the Alaska Geological Society, Book 50, v. 1, p. $545-558$.

Lee, M.W., Collett, T.S., and Agena, W.F., 2008, Assessing gas-hydrate prospects on the North Slope of AlaskaTheoretical considerations: U.S. Geological Survey Scientific Investigations Report 2008-5175, 28 p.

Lorenson,T.D., Collett, T.S., and Hunter, R.B., 2011, Gas geochemistry of the Mount Elbert Gas Hydrate Stratigraphic Test well, Alaska North Slope: Implications for gas hydrate exploration in the Arctic: Journal of Marine and Petroleum Geology, v. 28, p. 343-360.

Makogon, Y.F., 1981, Hydrates of natural gas: Tulsa, Okla., PennWell Publishing Company, 237 p.

Masterson, W.D., Dzou, L.I.P., Holba, A.G., Fincannon, A.L., and Ellis, Leroy, 2001, Evidence for biodegradation and evaporative fractionation in West Sak, Kuparuk, and Prudhoe Bay field areas, North Slope, Alaska: Organic Geochemistry, v. 32, p. 411-441.

Molenaar, C.M., Bird, K.J., and Kirk, A.R., 1987, Cretaceous and Tertiary stratigraphy of northeastern Alaska, in Tailleur, I.L., and Weimer, Paul, eds., Alaskan North Slope geology: Pacific Section, Society of Economic Paleontologists and Mineralogists and the Alaska Geological Society, Book 50, v. 1, p. $513-528$.
Molochushkin, E.N., 1973, The effect of thermal abrasion on the temperature of the permafrost in the coastal zone of the Laptev Sea: Moscow, U.S.S.R., Publishing House Nauka, Proceedings of the Second International Conference on Permafrost, Yakutsk, U.S.S.R., July 13-28, 1973, p. 90-93.

Mull, C.G., Houseknecht, D.W., and Bird, K.J., 2003, Revised Cretaceous and Tertiary stratigraphic nomenclature in the Colville Basin, northern Alaska: U.S. Geological Survey Professional Paper 1673, 51 p.

Ogg, J.G., Ogg, G.M., and Gradstein, F.M., 2008, The concise geologic time scale: Cambridge University Press, $177 \mathrm{p}$.

Osadetz, K.G., and Chen, Zhuoheng, 2005, A re-examination of Beaufort Sea-Mackenzie Delta Basin gas hydrate resource potential using a petroleum system approach: Proceedings of the Fifth International Conference on Gas Hydrates, Trondheim, Norway, June 13-16, 2005, 11 p.

Osterkamp, T.E., and Fei, Teng, 1993, Potential occurrence of permafrost and gas hydrates in the continental shelf near Lonely, Alaska: Washington, D.C., National Academy of Sciences, Proceedings of the Sixth International Conference on Permafrost, Beijing, China, July 5-9, 1993, p. 500-505.

Rose, K.K., Boswell, Ray, and Collett, T.S., 2011, Mount Elbert Gas Hydrate Stratigraphic Test well, Alaska North Slope: Coring operations, core sedimentology, and lithostratigraphy: Journal of Marine and Petroleum Geology, v. 28, p. 311-331.

Sloan, E.D., and Koh, C.A., 2008, Clathrate hydrates of natural gases: Boca Raton, Fla., CRC Press, 721 p.

Torres, M.E., Tréhu, A.M., Cespedes, N.D., Kastner, Miriam, Wortmann, U.G., Kim, J.H., Long, Philip, Malinverno, Alberto, Pohlman, J.W., Riedel, Michael, and Collett, T.S., 2008, Methane hydrate formation in turbidite sediments of northern Cascadia, IODP Expedition 311: Earth and Planetary Science Letters, v. 271, p. 170-180.

Werner, M.R., 1987, Tertiary and Upper Cretaceous heavy oil sands, Kuparuk River area, Alaskan North Slope, in Tailleur, I.L., and Weimer, Paul, eds., Alaskan North Slope geology: Pacific Section, Society of Economic Paleontologists and Mineralogists and the Alaska Geological Society, Book 50, v. 1, p. 109-118.

Xu, Wenyue, and Ruppel, Carolyn, 1999, Predicting the occurrence, distribution, and evolution of methane gas hydrate in porous marine sediments: Journal of Geophysical Research, v. 104 , p. $5081-5095$. 
Publishing support provided by:

Denver Publishing Service Center

For more information concerning this publication, contact: Center Director, USGS Central Energy Resources Science Center Box 25046, Mail Stop 939

Denver, CO 80225

(303) 236-1647

Or visit the Central Energy Resources Science Center Web site at: http://energy.usgs.gov/ 
